\title{
Vejle Diabetes Biobank - a resource for studies of the etiologies of diabetes and its comorbidities
}

This article was published in the following Dove Press journal:

Clinical Epidemiology

21 October 2016

Number of times this article has been viewed

\author{
Eva Rabing Brix Petersen ${ }^{1,2}$ \\ Aneta Aleksandra Nielsen' \\ Henry Christensen' \\ Torben Hansen ${ }^{3}$ \\ Oluf Pedersen ${ }^{3}$ \\ Cramer Kjeldahl \\ Christensen ${ }^{4}$ \\ Ivan Brandslund ${ }^{1,2}$
}

'Department of Clinical Immunology and Biochemistry, Lillebaelt Hospital, Vejle, ${ }^{2}$ Faculty of Health Sciences, Institute of Regional Health Research, University of Southern Denmark,

Odense, ${ }^{3}$ Novo Nordisk Foundation

Center for Basic Metabolic Research,

Section of Metabolic Genetics,

Faculty of Health and Medical

Sciences, University of Copenhagen,

Copenhagen, ${ }^{4}$ Department of Internal

Medicine and Endocrinology, Lillebaelt Hospital, Vejle, Denmark
Correspondence: Eva Rabing Brix Petersen

Department of Clinical Immunology and Biochemistry, Lillebaelt Hospital, Kabbeltoft 25, 7100 Vejle, Denmark

Tel +4579406500

Fax +457940 6853

Email eva.rabing.brix.petersen@rsyd.dk
Aims: Carefully designed and established biobanks are considered one of the most essential resources to foster biomedical research as they provide cost-effective and rapid access to a vast variety of biological materials and related anthropometrics allowing for testing of various biomarkers as well as numerous original and pertinent bioclinical hypotheses related to human disease etiology and prognosis. The objective of the present study was to present the baseline data, design, and methods used for the establishment of the Vejle Diabetes Biobank. Further aims included assessment of the prevalence of diabetes and quality of diabetes treatment in a specified Danish region.

Methods: The Vejle Diabetes Biobank was established from 2007 to 2010 as a regional Biobank containing blood, DNA, and urine samples from patients with diabetes and a gender- and age-matched control population aged 25-75 years. Anthropometrics were obtained by physical examination, questionnaires, and interviews at the time of inclusion into the Biobank. The cohort was linked to the Danish Civil Registration System, the Danish National Patient Registry, and the Danish National Prescription Registry.

Results: In total, 4,255 nondiabetic individuals and 3,320 patients with diabetes were included. Type 2 diabetes (T2D) patients had a higher body mass index $\left(30 \mathrm{~kg} / \mathrm{m}^{2}\right)$ than type 1 diabetes (T1D) patients ( 25 and $26 \mathrm{~kg} / \mathrm{m}^{2}$ in women and men, respectively) and control subjects ( 25 and $27 \mathrm{~kg} / \mathrm{m}^{2}$ in women and men, respectively). Fasting levels of plasma triglycerides and blood pressure were higher in T2D patients $(1.5 \mathrm{mmol} / \mathrm{L}$ and $148 / 85 \mathrm{mmHg}$, respectively) compared with T1D patients $(0.9 \mathrm{mmol} / \mathrm{L}$ and $139 / 81 \mathrm{mmHg}$, respectively), whereas glycated hemoglobin (HbA1c), plasma high density lipoprotein, low density lipoprotein, and total cholesterol were lower in T2D patients $(51 \mathrm{mmol} / \mathrm{mol}, 1.2 \mathrm{mmol} / \mathrm{L}, 2.2 \mathrm{mmol} / \mathrm{L}$, and $4.2 \mathrm{mmol} / \mathrm{L}$, respectively) compared with findings in T1D patients $(61 \mathrm{mmol} / \mathrm{mol}, 1.6 \mathrm{mmol} / \mathrm{L}, 2.3 \mathrm{mmol} / \mathrm{L}$, and 4.4 $\mathrm{mmol} / \mathrm{L}$, respectively). At the time of inclusion into the Biobank, $56 \%$ of the T2D patients and $25 \%$ of T1D patients had an HbAlc $<7 \%$ (53 mmol $/ \mathrm{mol}$ ). Only $28 \%$ and $34 \%$ of the T2D patients, respectively, reached treatment target for blood pressure and lipids.

Conclusion: The Vejle Diabetes Biobank represents one of the largest open diabetes case-control cohorts in Denmark. The Biobank invites collaborative investigations of diabetes and diabetes complication etiologies as well as studies of prognostic or predictive biomarkers.

Keywords: diabetes, type 2 diabetes, HbA1c, diabetes Biobank resource, research database

\section{Background}

Biobanks have become one of the most valuable resources in biomedical research ${ }^{1}$ as they provide cost-effective and rapid access to a vast spectrum of biological materials and related anthropometric data allowing for comprehensive studies, often to be shared by multiple research environments. Recently, a Canadian study ${ }^{2}$ suggested that 
biorepositories coordinating the activity of biobanking "rank among the most important of established health research infrastructures as contributors to research publications." Biobanking of human biological materials together with relevant coupling to national disease and mortality registries enable longitudinal follow-up, improved opportunity of understanding disease mechanism, and contribute to documentation of quality and lifelong patient outcomes.

The primary objective for establishing the Vejle Diabetes Biobank was to enable the investigation of prognostic and predictive values of a variety of possible etiological components. Further, to investigate the prognostic and predictive value of biomarkers for development of diabetes, its associated complications, and outcomes. Repeated data analyses were performed during follow-up on patients with time.

The objective of the present study is to present the baseline data, design, and methods used for the establishment of the Vejle Diabetes Biobank and provide information about the quality of diabetes patient treatment at the time of the establishment of the Biobank with the ultimate goal of providing information about the resource for national and international investigators in this research field.

\section{Materials and methods}

\section{Recruitment of study participants}

The Vejle Diabetes Biobank was established as a regional Biobank containing blood and urine samples from individuals with diabetes and a gender- and age-matched control population aged between 25 and 75 years (both ages included) as of the inclusion date per December 31, 2006.

Subjects eligible for the cohort were identified using information from the Civil Registration System. ${ }^{3,4}$ The identified diabetes and control populations were limited to individuals who were alive and residing in the former County of Vejle area on December 31, 2006. These eligible individuals received an information letter asking them to participate in the Biobank as diabetes or control subjects, respectively. In case of not responding, an information letter was sent as a reminder. The subjects participating were not given any compensation for their donation of blood and urine.

Individuals who responded positively subsequently received a questionnaire (Supplementary material) to fill in at home and were given an appointment at one out of four hospitals in the predefined region of Denmark (Vejle, Kolding, Fredericia, and Horsens) for anthropometric examinations and biological sampling. The participants were asked to fast overnight from 10 p.m. and to abstain from physical activity 72 hours before their appointment for entering the Biobank.
They were examined by laboratory technicians or healthcare assistants at the respective hospital and the completed questionnaire was reviewed together with the participant. The patients' verification of the diabetes diagnosis was considered the gold standard, 5 thus, only subjects acknowledging having diabetes were included in the diabetes cohort. The participants requested as control individuals were likewise asked if they acknowledged not having diabetes. Only subjects acknowledging no diabetes were included in the control cohort.

\section{The inclusion and exclusion criteria for the diabetic cohort}

The patients with diabetes were identified by the following inclusion criteria of which at least one criteria had to be met: A) At least one glycated hemoglobin (HbA1c) value $\geq 6.6 \%$ $(\geq 48.6 \mathrm{mmol} / \mathrm{mol})$ registered in the Clinical Laboratory Information System (LABKA), ${ }^{6}$ in the period from January 1996 to December 2006. B) At least three HbA1c values $<6.6 \%(48.6 \mathrm{mmol} / \mathrm{mol})$ registered in LABKA in the period from January 2002 to December 2006. C) Patients registered in the Danish National Prescription Registry ${ }^{7}$ with at least one prescription handled in the former County of Vejle in the period from January 1, 2006 to December 31, 2006 for oral antidiabetic agents or insulin with the Anatomical Therapeutic Chemical (ATC) Classification System ${ }^{8}$ code A10A (insulin) and/or A10B (oral antidiabetic agents). D) All patients registered in the Danish National Patient Registry ${ }^{9}$ with a contact (inpatient- or outpatient-based) in the period from 1977 to December $2006^{10}$ at hospitals in the former County of Vejle with a diabetes diagnosis (both primary and secondary diagnoses) (International Classification of Diseases [ICD] code 250 [Eighth Revision] and/or codes DE10 and/or DE11 [Tenth Revision] [ICD10], which is in use since 1994 in Denmark). ${ }^{11}$

Based on the above-mentioned four criteria, the eligible study participants for the diabetes sample comprised of 14,831 patients who potentially might suffer from diabetes, of whom 3,345 were excluded due to age under 25 or age above 75 years.

In order to minimize the enrolment of individuals with a different genetic background than Danish, individuals with a non-Danish first name and/or last name were not asked to participate in the Biobank ( $n=647$ corresponding to $6 \%$ of the diabetic population selected). Detailed information on the inclusion of diabetes patients is given in flow diagram 1 (Figure 1). In total, 10,408 potential diabetic individuals were asked to participate in the Vejle Diabetes Biobank, whereof 4,174 responded positively (response rate of $40 \%$ ). In total, 3,320 individuals consented to join the Vejle Diabetes Biobank 


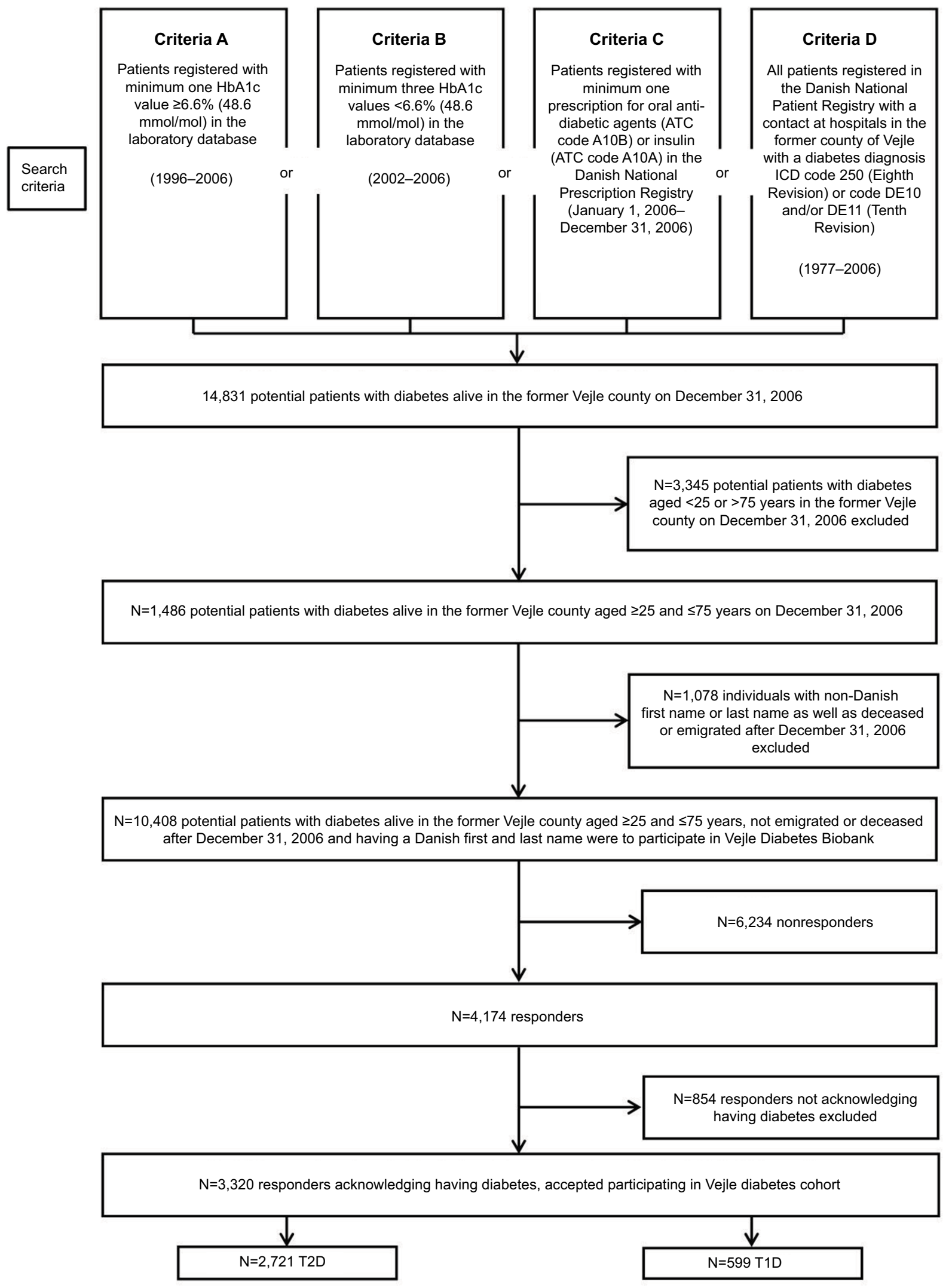

Figure I Selection of patients with diabetes for the Vejle Diabetes Biobank.

Abbreviations: ATC, Anatomical Therapeutic Chemical; ICD, International Classification of Diseases; TID, type I diabetes; T2D, type 2 diabetes; HbAlc, glycated hemoglobin. 
as patients with diabetes. The patients were classified according to their own statement as either type 1 diabetes (T1D) or type 2 diabetes (T2D) patients as previously validated by Kristensen et al. ${ }^{5}$ Patients who did not have knowledge of their own classification $(\sim 2 \%)$ were stratified based on the following criteria for T2D and T1D, respectively; T2D: diabetes debut after the age of 30 years and treatment with oral antidiabetic agents (ATC Classification System code A10B) for at least 1 year following time of diagnosis and/or dietary treatment after diagnosis, and T1D: treatment with insulin or insulin analogues from time of diagnosis (ATC Classification System code A10A) without any oral antidiabetic agents (ATC Classification System code A10B). According to the above stated criteria, 599 patients were classified as T1D patients and 2,721 patients were classified as T2D patients (Figure 1).

\section{Inclusion and exclusion criteria for individuals in the control cohort}

The individuals for the control cohort were selected by the Danish Civil Registration System from the background population of the former County of Vejle, Denmark ( $n=360,921)$. Planned sampling was $1: 1$.

All citizens of the County of Vejle aged $\geq 25$ and $\leq 75$ years $(n=229,551)$ and alive at the inclusion date December 31, 2006 were divided into 10-year age intervals in order to obtain a random control from the background population, and gender-matched to the diabetes population, subsequently randomly selected. Of the 11,065 control subjects who received a request to participate in the Biobank, 4,290 chose to participate (response rate of 39\%). Thirty-five subjects who did not fulfill any of the four diabetes criteria A-D but acknowledged having diabetes were excluded from the control population. In total, the control population constituted of 4,255 individuals without diabetes. Detailed information on the inclusion of the control persons is given in flow diagram 2 (Figure 2).

\section{Anthropometrics}

The following anthropometrics were examined during the visit at the enrolment in the Vejle Diabetes Biobank: height (ultrasound height rod, Soehnle Industrial Solutions GmbH, Backnang, Germany), weight with indoor clothes but without shoes, body mass index (BMI) calculated by dividing weight in kilograms by the squared height in meters, ${ }^{12}$ body fat percentage (Tanita Body Composition Analyzer 418, IL, USA), waist and hip circumference was measured according to World Health Organization standard, ${ }^{13}$ and systolic and diastolic blood pressures were measured after 5 minutes rest in sitting position (Omron M5 Professional, Osaka, Japan).
The following information was obtained through the questionnaire: smoking status (daily, occasionally, formersmoker, ever-smoker), alcohol consumption (none, occasionally, 1-7 units per week, 7-14 units per week, 14-21 units per week, more than 21 units per week), exercise habit (no, yes; if yes: number of times per week, number of minutes per time; low intensity, moderate intensity, high intensity), gestational diabetes (yes, no), age at onset of diabetes, heart diseases (eg, acute myocardial infarction, angina pectoris, congestive heart failure), cerebral diseases (eg, stroke), late diabetic complications: eyes, kidneys, nerves, foot ulcers (yes, no, not known), diabetes in parents/siblings and/or children (yes, no), diabetes medication (insulin, glucagon-like peptide 1 analogues/ dipeptidyl peptidase IV inhibitors, biguanides [metformin] alone or in drug combinations, $\beta$-cell stimulating drugs [ie, sulfonylurea and meglitinides], alpha-glucosidase inhibitors, glitazones), and other medication (cholesterol-lowering agents, anticoagulants, antihypertensive drugs (angiotensin converting enzyme [ACE]-inhibitors, angiotensin 2 receptor [AT2]-antagonists, $\beta$-blockers, calcium antagonists, renininhibitors, diuretics, other). ${ }^{14}$

Advocating and advertising for participating in the biobank were repeatedly done in the local media and information flyers were distributed at the general practitioners in the local area and the outpatient clinics at the four hospitals participating in the recruitment as an attempt to improve the response rate.

\section{Biological sample collection and storage conditions}

In the period from March 1, 2007 to May 1, 2010, blood (125 $\mathrm{mL})$ and urine $(10 \mathrm{~mL}$, first-morning urine sample brought by the participant) samples were collected from each participant at attendance and plasma, serum, and buffy coat were separated, aliquoted, and stored at $-80^{\circ} \mathrm{C}$ until analysis. ${ }^{14}$ In total, for every subject, 56 tubes of serum, ethylenediaminetetraacetic acid (EDTA)- and Li-heparin plasma, EDTA whole blood, and buffy coat were stored centrally at Vejle Hospital.

Blood samples were analyzed for $\mathrm{HbA1c}$, fasting plasma glucose (FPG), C-peptide, triglycerides, total cholesterol, high and low density lipoproteins (HDL, LDL), middle sensitive CRP (measurable down to $0.3 \mathrm{mg} / \mathrm{L}$ ), p-albumin, calcium, alanine aminotransferase (ALAT), and p-creatinine. Due to financial restrictions, ALAT and p-creatinine in the control population were analyzed in February 2016 on Cobas 8000 (Hoffmann-La Roche Ltd., Basel, Switzerland), whereas in the diabetes population it was analyzed in 2009-2010 on a Modular P system (Hoffmann-La Roche Ltd.). Urine samples in the diabetes cohort were analyzed for U-albumin, U-creatinine, 
$\mathrm{N}=360,921$ inhabitants in former Vejle county, December 31, 2006

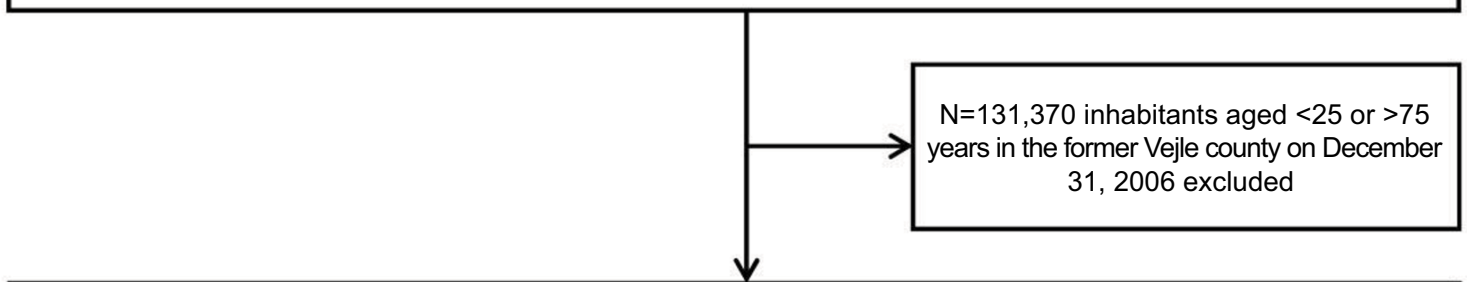

$\mathrm{N}=229,551$ inhabitants in former Vejle county aged $\geq 25$ and $\leq 75$ years on December 31, 2006

Divided into 10-year intervals and gender matched to the diabetes population, subsequently randomly selected

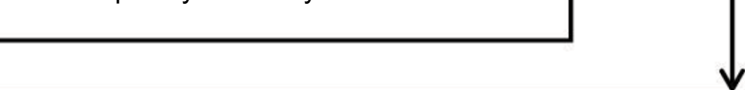

$\mathrm{N}=12,280$ women and men in former Vejle county aged $\geq 25$ and $\leq 75$ years

on December 31, 2006

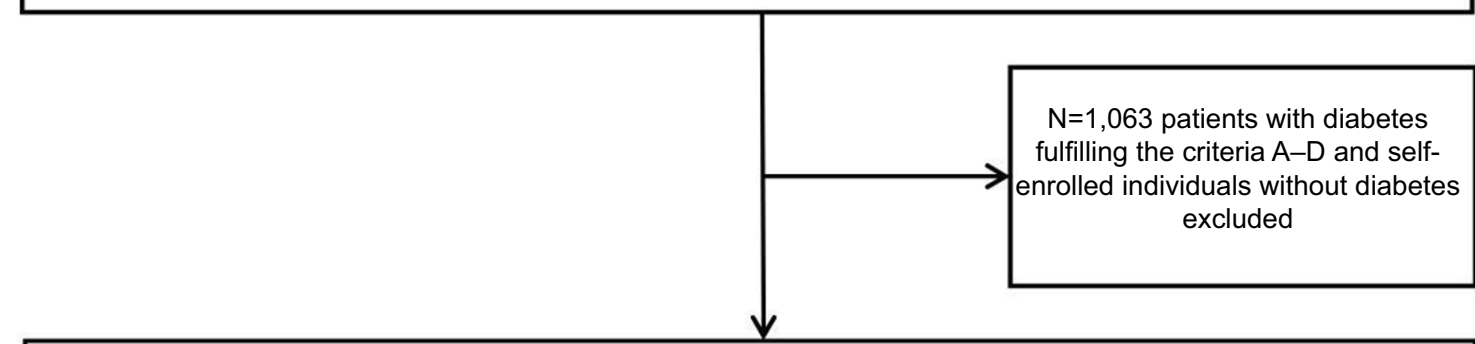

$\mathrm{N}=11,217$ women and men in former Vejle county aged $\geq 25$ and $\leq 75$ years, not fulfilling the criteria $A-D$, not selfenrolled, on December 31, 2006

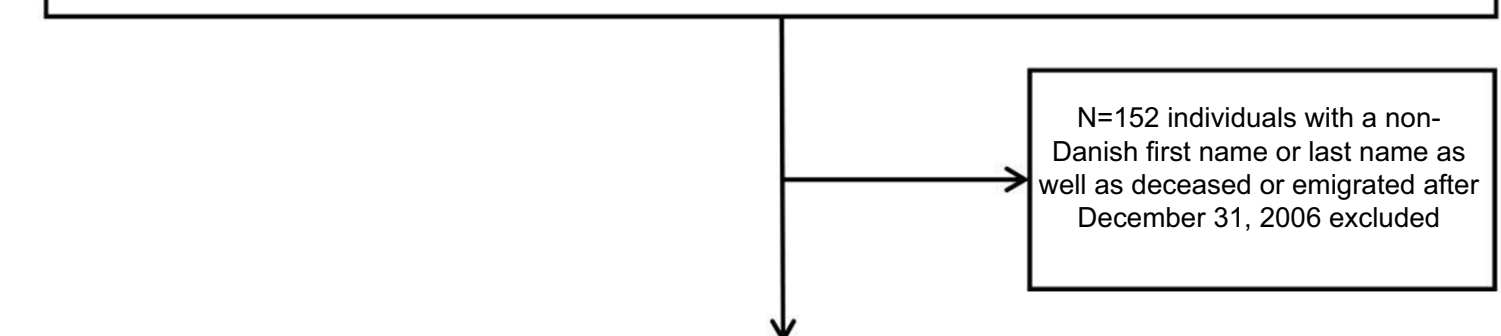

$\mathrm{N}=11,065$ women and men in former Vejle county aged $\geq 25$ and $\leq 75$ years, not fulfilling the criteria A-D, not selfenrolled, not emigrated, or deceased and having a Danish first and last name on December 31, 2006, were asked to participate

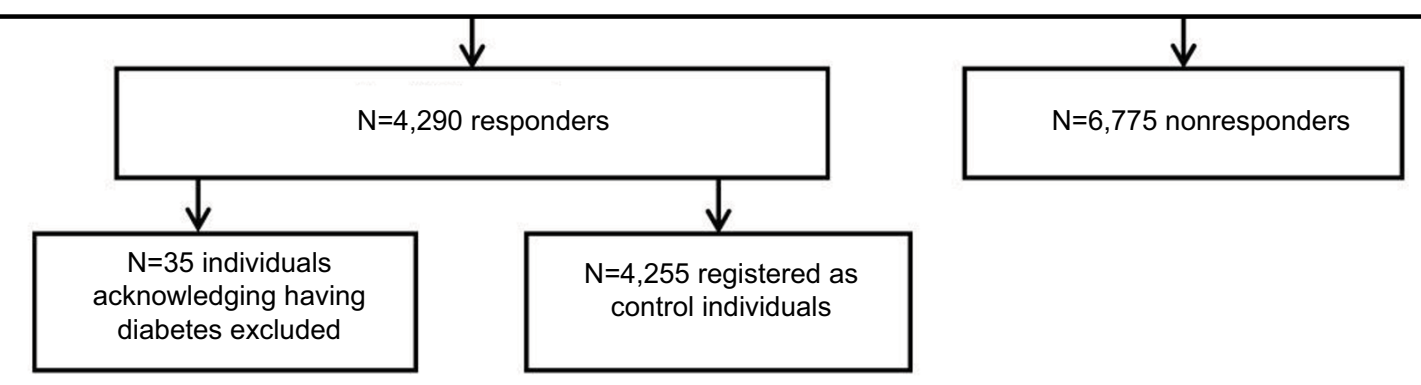

Figure 2 Selection of participants without diabetes for the Vejle Diabetes Biobank. 
U-protein, and U-albumin/creatinine ratio. GFR was estimated by the use of the CKD-EPI equation. ${ }^{15}$

Venous blood for FPG measurements was drawn from an antecubital vein in tubes containing Li-heparin (Venosafe ${ }^{\circledR}$, Terumo Europe NV, Leuven, Belgium). The samples were immediately cooled in ice water, centrifuged at $5^{\circ} \mathrm{C}$ at $3,000 \times$ $g$ for 10 minutes, and plasma separated within 30 minutes. ${ }^{16}$ Aliquots of plasma were stored at $-80^{\circ} \mathrm{C}$ until analysis. Glucose measurements as well as triglycerides, total cholesterol, HDL, LDL, CRP, p-albumin, calcium, ALAT, p-creatinine, U-albumin, U-creatinine, U-protein, and U-albumin/creatinine ratio were performed on a Modular P system (HoffmannLa Roche Ltd.). Total imprecision and analytical bias were controlled by external HK1 control material purchased from the Danish Institute for External Quality Assurance for Laboratories in Health Care, Glostrup, Denmark. ${ }^{17}$ The analyses performed in the laboratory fulfilled the generally accepted criteria for bias and coefficient of variation. ${ }^{18,19}$

All samples were thawed in an incubator until reaching a temperature of $37^{\circ} \mathrm{C}$, then mixed by vortexing and centrifuged at $2,000 \times g$ for 10 minutes before analyzing. Whole blood samples for HbA1c measurements were drawn from the same puncture as for FPG analysis. Samples were collected in tubes containing EDTA (K3E, Venosafe) and stored at $-80^{\circ} \mathrm{C}$ until analysis. ${ }^{14} \mathrm{HbA} 1 \mathrm{c}$ analysis was carried out on a fully automated glycohemoglobin analyzer (Tosoh HLC-723 G7, Tosoh, Tessenderlo, Belgium) with total analytical imprecision $<1.8 \%$ Diabetes Control and Complication Trial (DCCT) in the range $5.0-9.0 \mathrm{HbA} 1 \mathrm{c} \%$, corresponding to $<2.7 \%$ International Federation of Clinical Chemistry (IFCC) in the range 31-75 mmol/mol. ${ }^{16}$ Analytical bias was assessed by external control materials (no. 3044 F1) from Labquality ${ }^{20}$ and in the analyzing period positive bias was measured below $3.5 \%$ in the range $5.0 \%-9.0 \%$ in DCCT units (below $5.2 \%$ IFCC in the range $31-75 \mathrm{mmol} / \mathrm{mol}$ ), which was acceptable according to the DCCT/National Glycohemoglobin Standardization Program criteria. ${ }^{21} \mathrm{C}$-peptide was analyzed on an Advia Centaur System (Siemens Healthineers, Erlangen, Germany).

\section{Sample size and selection considerations}

The goal of the establishment of the Vejle Diabetes Biobank was to include all patients with T2D aged between 25 and 75 years in the former Vejle County. All patients with possible diabetes were thus primarily elected. For case-control genotyping studies, statistical power calculation demonstrated a power allowing for the detection of common genetic risk variants with an allele frequency of $>10 \%$ with a relative risk (RR) of 1.3 based on the inclusion of 1,000 patients with T2D (cases) and 1,000 control persons. At allele frequency of $>35 \%$ in the same setup, the calculation demonstrated a statistical power of $80 \%$ for the identification of genetic risk variants with an RR of 1.2. In this study having more than 2,000 cases and over 4,000 controls, a statistical power of $80 \%$ will allow for identification of genetic risk variants with an allele frequency of $>8 \%$ with an RR of 1.3 .

\section{Follow-up}

The prospect of the Biobank was estimated to 10-15 years with consecutive follow-up data analysis on the existing data without repeated sampling.

\section{Data sources}

The cohort was linked to the Danish Civil Registration System $^{3,4}$ and the Danish National Patient Registry ${ }^{9}$ in 2011 and again in August 2015. Since the establishment in 1968, the Civil Registration System identifies all living and deceased persons in Denmark by using the Danish Personal Identification Number. This is a 10-digit number unique for every citizen ${ }^{4}$ and used for all purposes involving health care, social, and administrative transactions. The Danish Civil Registration System provides information about vital status, emigration, or in case of deceased subjects the date of death, whereas the Danish National Patient Registry contains records of all hospital contacts (in- and outpatient) and ICD8 and ICD10 diagnostic codes. ${ }^{10,22}$ The Danish National Prescription Registry ${ }^{7}$ was accessed in the initial phase in order to find patients registered with at least one prescription in the period from January 1, 2006 to December 31, 2006 for oral antidiabetic agents or insulin. LABKA was accessed in order to obtain the laboratory data produced.

\section{Validation of the anthropometrics}

Data were visualized by graphic presentation and checked for reliability and consistency. Flawed data were corrected according to primary data source.

\section{Treatment goals}

The latest recommended target for glycemic regulation in nonpregnant adults with diabetes is $\mathrm{HbAlc}<7.0 \%$ (53 mmol/ $\mathrm{mol}$ ), although it is recognized that some diabetes patients may benefit from less strict control (HbA1c $<7.5 \%-8.0 \%, 58-64$ $\mathrm{mmol} / \mathrm{mol}$ ) and others from a more rigorous control (HbA1c $<6.0 \%-6.5 \%, 42-48 \mathrm{mmol} / \mathrm{mol}) .{ }^{23-27}$ For these reasons, the analyses of the diabetes cohort at several HbAlc limits were done. For comparison over time, the authors also did the analysis with a target limit for normalization of $\mathrm{HbA} 1 \mathrm{c}$ of $6.6 \%(48.6 \mathrm{mmol} / \mathrm{mol})$ corresponding to the 99.9 percentile limit in a nondiabetic population in the former Vejle County 
as previously documented. ${ }^{28}$ This limit was also used in the inclusion criteria A and B for the diabetes population.

Regarding hypertension, it is recommended to maintain the systolic blood pressure below $140 \mathrm{mmHg}$ and the diastolic blood pressure below $90 \mathrm{mmHg} .{ }^{29}$ The guidelines on antihypertensive treatment in diabetes patients recommend either an ACE-inhibitor or AT2 antagonist as first choice.

In managing the dyslipidemia closely related to $\mathrm{T} 2 \mathrm{D}$, it is recommended to treat patients aged $\geq 40$ years with statins, dosage dependent on the presence of cardiovascular disease risk factors. ${ }^{29}$ The targets are triglycerides $<1.7 \mathrm{mmol} / \mathrm{L}$ (150 $\mathrm{mg} / \mathrm{dL}), \mathrm{LDL}<2.6 \mathrm{mmol} / \mathrm{L}(100 \mathrm{mg} / \mathrm{dL}), \mathrm{HDL} \geq 1.0 \mathrm{mmol} / \mathrm{L}$ ( $40 \mathrm{mg} / \mathrm{dL})$ for men and $\geq 1.3 \mathrm{mmol} / \mathrm{L}(50 \mathrm{mg} / \mathrm{dL})$ for women, and total cholesterol $<4.5 \mathrm{mmol} / \mathrm{L}$.

\section{Statistical methods}

Normally distributed data are presented as mean \pm standard deviation; nonparametric data are presented as median and
25-75 percentiles. For the statistical analyses, SPSS version 23 (IBM Corporation, Armonk, NY, USA) and the R project for statistical programming (R version 3.2.3) were used.

\section{Ethics}

The study was approved by the Danish Data Protection Agency (j. no. 2006-53-1385 and j. no. 2008-58-0035) and by The Regional Scientific Ethical Committees for Southern Denmark (j. no. S-20080097).

\section{Results}

In total, 4,255 control persons with no diabetes and 3,320 patients with diabetes, hereof 2,721 T2D patients and 599T1D patients, were included from March 1, 2007 to May 1, 2010.

\section{Anthropometrics and biochemistry}

The baseline characteristics of the study participants in the Vejle Diabetes Biobank are described in Table 1. It is evident

Table I Baseline characteristics of the study population in the Vejle Diabetes Biobank

\begin{tabular}{|c|c|c|c|c|}
\hline $\begin{array}{l}\text { Variable } \\
\text { Median (25-75 quartiles) unless stated } \\
\text { otherwise }\end{array}$ & $\begin{array}{l}\text { Type } 2 \text { diabetes } \\
\text { (T2D) patients }\end{array}$ & $\begin{array}{l}\text { Type I diabetes } \\
\text { (TID) patients }\end{array}$ & Control population & $\begin{array}{l}\text { Missing } n^{a}(T 2 D / \\
\text { TID/control } \\
\text { population) }\end{array}$ \\
\hline Enrolled, $\mathrm{n}$ & 2,721 & 599 & 4,255 & \\
\hline \multicolumn{5}{|l|}{ Sex, n (\%) } \\
\hline Female & I,052 (39) & $234(39)$ & I,873 (44) & \\
\hline Male & $1,669(61)$ & $365(6 I)$ & $2,382(56)$ & \\
\hline Age, December 3I, 2006 (years) & $62(56-68)$ & $5 I(4 \mid-6 I)$ & $59(51-65)$ & \\
\hline Age at time of diagnosis (years) & $56(49-62)$ & $30(17-42)$ & Not relevant & $202 / 27$ \\
\hline Median years diagnosed (years) & $4(\mathrm{I}-8)$ & $18(9-29)$ & Not relevant & $202 / 27$ \\
\hline \multicolumn{5}{|l|}{ Height $(\mathrm{cm})$} \\
\hline Women & $162(158-167)$ & $166(162-170)$ & $165(160-169)$ & $1 / 0 / 0$ \\
\hline Men & $\mid 75(|7|-\mid 79)$ & $178(|73-| 8 \mid)$ & $177(\mid 72-180)$ & $1 / 1 / 0$ \\
\hline \multicolumn{5}{|l|}{ Weight (kg) } \\
\hline Women & $80(71-93)$ & $68(60-77)$ & $67(60-77)$ & $6 / 0 / 1$ \\
\hline Men & $91(82-103)$ & $80(72-90)$ & $83(75-92)$ & $2 / 1 / 2$ \\
\hline \multicolumn{5}{|l|}{$\mathrm{BMI}\left(\mathrm{kg} / \mathrm{m}^{2}\right)$} \\
\hline Women & $30(27-35)$ & $25(22-28)$ & $25(22-28)$ & $6 / 0 / 1$ \\
\hline Men & $30(27-33)$ & $26(23-28)$ & $27(25-29)$ & $2 / 1 / 2$ \\
\hline \multicolumn{5}{|l|}{ Waist (cm) } \\
\hline Women & $101(93-111)$ & $84(79-94)$ & $85(77-93)$ & $3 / 2 / 0$ \\
\hline Men & $106(98-115)$ & $93(87-101)$ & $97(91-104)$ & $4 / 2 / 1$ \\
\hline \multicolumn{5}{|l|}{ Hip (cm) } \\
\hline Women & $109(102-118)$ & $100(93-107)$ & $98(92-105)$ & $4 / 4 / 0$ \\
\hline Men & $106(101-112)$ & $100(96-105)$ & $101(97-106)$ & $4 / 1 / 2$ \\
\hline \multicolumn{5}{|l|}{ Waist-hip ratio } \\
\hline Women & $0.92(0.87-0.96)$ & $0.86(0.82-0.90)$ & $0.87(0.82-0.91)$ & $4 / 4 / 0$ \\
\hline Men & $0.99(0.96-1.03)$ & $0.94(0.89-0.99)$ & $0.96(0.93-1.00)$ & $4 / 2 / 2$ \\
\hline \multicolumn{5}{|l|}{ Blood pressure $(\mathrm{mmHg})$} \\
\hline Systolic & $148(136-162)$ & $139(127-154)$ & $142(128-157)$ & $29 / 10 / 33$ \\
\hline Diastolic & 85 (79-92) & $8 \mathrm{I}(74-88)$ & $86(79-94)$ & $31 / 10 / 33$ \\
\hline \multicolumn{5}{|l|}{ Glycemic parameters } \\
\hline $\mathrm{HbAlc} \mathrm{c}^{\mathrm{b}}(\mathrm{mmol} / \mathrm{mol})$ & $51(45-58)$ & $61(53-68)$ & 37 (34-39) & $11 / 2 / 4$ \\
\hline HbAlc (\%) & $6.8(6.3-7.5)$ & $7.7(7.0-8.4)$ & $5.5(5.3-5.7)$ & $\mathrm{II} / 2 / 4$ \\
\hline Fasting plasma glucose (mmol/L) & $8.1(7.0-9.6)$ & $9.4(6.8-13.1)$ & $5.6(5.2-5.9)$ & $9 / 0 / 17$ \\
\hline C-peptide (pmol/L) & $677(450-904)$ & $10(10-102)$ & $453(346-628)$ & $43 / 14 / 140$ \\
\hline
\end{tabular}

(Continued) 
Table I (Continued)

\begin{tabular}{|c|c|c|c|c|}
\hline $\begin{array}{l}\text { Variable } \\
\text { Median (25-75 quartiles) unless stated } \\
\text { otherwise }\end{array}$ & $\begin{array}{l}\text { Type } 2 \text { diabetes } \\
\text { (T2D) patients }\end{array}$ & $\begin{array}{l}\text { Type I diabetes } \\
\text { (TID) patients }\end{array}$ & Control population & $\begin{array}{l}\text { Missing } \mathrm{n}^{\mathrm{a}}(\mathrm{T} 2 \mathrm{D} / \\
\text { TID/control } \\
\text { population) }\end{array}$ \\
\hline \multicolumn{5}{|l|}{ Lipids (mmol/L) } \\
\hline Total cholesterol & $4.2(3.7-4.8)$ & $4.4(3.9-4.9)$ & $5.3(4.6-6.0)$ & $9 / 1 / 15$ \\
\hline LDL & $2.2(1.8-2.7)$ & $2.3(3.9-4.9)$ & $3.2(2.6-3.8)$ & $9 / 2 / 15$ \\
\hline HDL & $1.2(1.0-1.5)$ & $1.6(1.3-1.9)$ & $1.5(1.2-1.8)$ & $9 / 0 / 15$ \\
\hline Triglycerides & I.5 (I.I-2.2) & $0.9(0.7-1.3)$ & $1.1(0.8-1.5)$ & $9 / 0 / 15$ \\
\hline CRP $(\mathrm{mg} / \mathrm{L})($ ref. $<6)$ & $1.9(0.9-4.2)$ & I.2 (0.5-2.6) & $1.3(0.6-2.8)$ & $9 / 0 / 17$ \\
\hline Calcium (mmol/L) & $2.29(2.24-2.35)$ & $2.27(2.20-2.33)$ & $2.26(2.20-2.31)$ & $9 / 0 / 16$ \\
\hline \multicolumn{5}{|l|}{ ALAT (U/L) } \\
\hline Women (ref. 10-45) & $23(18-32)$ & $20(15-25)$ & $20(16-27)$ & $10 / 3 / 19$ \\
\hline Men (ref. 10-70) & $27(20-38)$ & $24(18-32)$ & $26(2 \mid-37)$ & $20 / 1 / 30$ \\
\hline P-albumin $(g / L)$ & $45(44-47)$ & $44(43-46)$ & $45(43-46)$ & $9 / 0 / 17$ \\
\hline \multicolumn{5}{|l|}{ Renal parameters } \\
\hline \multicolumn{5}{|l|}{ P-creatinine $(\mu \mathrm{mol} / \mathrm{L})$} \\
\hline Women (ref. 45-90) & $68(60-79)$ & $68(62-76)$ & $74(65-82)$ & $9 / 3 / 16$ \\
\hline Men (ref. 60-105) & $84(75-96)$ & $82(74-94)$ & $91(8 I-10 I)$ & $14 / 0 / 24$ \\
\hline $\operatorname{eGFR}^{c}\left(\mathrm{~mL} / \mathrm{min} / \mathrm{l} .73 \mathrm{~m}^{2}\right)$ & $83(70-94)$ & $92(77-102)$ & $78(67-90)$ & $23 / 3 / 40$ \\
\hline U-albumin (mg/L) & $7(4-12)$ & $7(4-14)$ & n.a. & $7 / 4 / 4,246$ \\
\hline U-creatinine $(\mu \mathrm{mol} / \mathrm{L})$ & $8(5-I I)$ & $7(5-12)$ & n.a. & $8 / 4 / 4,246$ \\
\hline U-albumin/creatinine ratio $(\mathrm{mg} / \mathrm{g})$ & $9(5-17)$ & $8(5-16)$ & n.a. & $13 / 8 / 4,246$ \\
\hline \multicolumn{5}{|l|}{ Smoking status, n (\%) } \\
\hline Never & $913(34)$ & $233(39)$ & $\mathrm{I}, 664(39)$ & \\
\hline Former & $|, 23|(45)$ & $198(33)$ & $\mathrm{I}, 707(40)$ & \\
\hline Current & $57 \mid(2 I)$ & $168(28)$ & $873(21)$ & \\
\hline \multicolumn{5}{|l|}{ Antidiabetic treatment, $\mathrm{n}(\%)$} \\
\hline Oral exclusively & $\mathrm{I}, 535(56)$ & $8(1)$ & & \\
\hline Insulin and oral & $289(\mathrm{II})$ & $22(4)$ & & \\
\hline Insulin exclusively & $305(1 \mathrm{I})$ & $455(76)$ & & \\
\hline None & $592(22)$ & $114(19)$ & $4,255(100)$ & \\
\hline Antihypertensive treatment, $\mathrm{n}(\%)$ & 2,136 & 329 & 1,172 & \\
\hline ACE-inhibitors ${ }^{d}$ & $\mathrm{I}, \mathrm{I} 22(53)$ & $204(62)$ & $349(30)$ & \\
\hline AT2 antagonists ${ }^{e}$ & $704(33)$ & $113(34)$ & $245(21)$ & \\
\hline Calcium blockers & $776(36)$ & $133(40)$ & $397(34)$ & \\
\hline$\beta$-Blockers & $78(34)$ & $88(27)$ & $381(33)$ & \\
\hline Diuretics & $1,192(56)$ & $178(54)$ & $603(5 \mathrm{I})$ & \\
\hline Renin inhibitors & $8(0.4)$ & $\mathrm{I}(0.3)$ & I (0.09) & \\
\hline \multicolumn{5}{|l|}{ Alcohol consumption } \\
\hline \multicolumn{5}{|l|}{ Women, n (\%) } \\
\hline None & $483(46)$ & $80(34)$ & $321(17)$ & \\
\hline Occasionally & $173(16)$ & $18(8)$ & $321(17)$ & \\
\hline $\mathrm{I}-7$ units/week & $315(30)$ & $104(44)$ & $849(45)$ & \\
\hline 7-14 units/week & $58(6)$ & $22(9)$ & $297(16)$ & \\
\hline$|4-2|$ units/week & $20(2)$ & $9(4)$ & $72(4)$ & \\
\hline$>2$ I units/week & $2(0.2)$ & $0(0)$ & $10(0.5)$ & \\
\hline \multicolumn{5}{|l|}{ Men, n (\%) } \\
\hline None & $325(19)$ & $68(19)$ & $180(8)$ & \\
\hline Occasionally & $219(13)$ & $35(10)$ & $243(10)$ & \\
\hline I-7 units/week & $680(4 I)$ & $156(43)$ & $1,015(43)$ & \\
\hline $7-14$ units/week & $238(14)$ & $53(15)$ & $481(20)$ & \\
\hline |4-2| units/week & $149(9)$ & $37(10)$ & $339(14)$ & \\
\hline$>21$ units/week & $57(3)$ & $16(4)$ & $123(5)$ & \\
\hline Lipid lowering medicationf, n (\%) & $2004(74)$ & $325(54)$ & $692(16)$ & \\
\hline$\geq 40$ years and on statins, $n$ (\%) & $1983(74)$ & $295(63)$ & $690(17)$ & \\
\hline First-degree relative with diabetes, $\mathrm{n}(\%)$ & $1,300(48)$ & $233(39)$ & $908(21)$ & \\
\hline
\end{tabular}

Notes: aMissing numbers (n) for T2D/TID/Control population, respectively, b $\mathrm{HbAlc}$ IFCC mmol/mol $=10.93 \times \mathrm{HbAlc}$ DCCT \% -23.54 , ceGFR estimated by the use of the CKD-EPI equation, ${ }^{\mathrm{d}}$ Angiotensin-converting-enzyme inhibitors, ${ }^{\mathrm{e}}$ Angiotensin 2 receptor antagonists, 'Lipid-lowering medication: simvastatin, fibrates, and nicotinic acid. Abbreviations: ALAT, alanine aminotransferase; BMI, body mass index; DCCT, Diabetes Control and Complication Trial; IFCC, International Federation of Clinical Chemistry; HDL, high density lipoprotein; LDL, low density lipoprotein; HbAlc, glycated hemoglobin; n.a., not available. 
that T2D patients were heavier and had a higher median BMI (30 and $30 \mathrm{~kg} / \mathrm{m}^{2}$ in women and men, respectively) than T1D patients ( 25 and $26 \mathrm{~kg} / \mathrm{m}^{2}$ in women and men, respectively) and control subjects (25 and $27 \mathrm{~kg} / \mathrm{m}^{2}$ in women and men, respectively). Plasma triglycerides and blood pressure were higher in T2D patients $(1.5 \mathrm{mmol} / \mathrm{L}$ and $148 / 85 \mathrm{mmHg}$, respectively) compared with T1D patients $(0.9 \mathrm{mmol} / \mathrm{L}$ and 139/81 mmHg, respectively), whereas plasma HDL was lower in T2D patients $(1.2 \mathrm{mmol} / \mathrm{L})$ than in T1D patients $(1.6$ $\mathrm{mmol} / \mathrm{L})$. HbA1c was lower in T2D patients $(51 \mathrm{mmol} / \mathrm{mol})$ compared to T1D patients $(61 \mathrm{mmol} / \mathrm{mol})$; moreover, plasma LDL and total cholesterol levels were lower in T2D patients ( 2.2 and $4.2 \mathrm{mmol} / \mathrm{L}$, respectively) compared to T1D patients (2.3 and $4.4 \mathrm{mmol} / \mathrm{L}$ ). Plasma levels of CRP and ALAT in women were, despite being in normal range, elevated in T2D patients compared with both controls and T1D patients. The plasma concentration of ALAT in men was higher in T2D patients compared to T1D patients.

\section{Quality of diabetes care}

The distribution of patients fulfilling key quality criteria for diabetes treatment is demonstrated in Tables 2 and Table 3A, B.
As shown in Table 2, 56\% and 32\% of patients with T2D, respectively, had $\mathrm{HbA} 1 \mathrm{c}<7.0 \%$ and $<6.5 \%$, at time of inclusion into the cohort (2007-2010). Correspondingly for patients with T1D, 25\% and $11 \%$ presented with $\mathrm{HbA} 1 \mathrm{c}$ $<7.0 \%$ and $<6.5 \%$, respectively. In this period, $37 \%(42 \%$ of $\mathrm{T} 2 \mathrm{D}$ and $16 \%$ of T1D) were below the 99.9 percentile limit of $6.6 \%$ (Table 2). The percentage of patients reaching the recommended treatment targets for blood pressure and circulating levels of triglycerides, LDL, and HDL is visualized in Table $3 \mathrm{~A}$, B. HbA1c $<7 \%$, systolic blood pressure, triglycerides, and LDL cholesterol are depicted in Figures 3 and $4 \mathrm{~A}-\mathrm{C}$.

In this Vejle cohort, $28 \%$ of the T2D patients achieved the treatment target for blood pressure $(140 / 90 \mathrm{mmHg})$ compared with $48 \%$ in T1D patients (Table 4 ); $81 \%$ and $89 \%$ of T2D and T1D patients, respectively, were treated with at least an ACE-inhibitor or AT2 antagonist, whereas only $50 \%$ of the control population treated with antihypertensive agents received an ACE-inhibitor or AT2 antagonist.

Of the 2,721 patients with T2D, 74\% were treated with cholesterol-lowering agents, and among the T2D patients aged $\geq 40$ years, $74 \%$ received statins. However, the percentage of

Table 2 Number and percentage of subjects in each group reaching stated criteria for $\mathrm{HbAlc}$

\begin{tabular}{|c|c|c|c|c|}
\hline Population (N) & $\begin{array}{l}\text { HbAlc }<6.5 \%(48 \mathrm{mmol} / \mathrm{mol}) \\
\%\left(\mathrm{n} / \text { population } \mathrm{n}^{\mathrm{a}}\right)\end{array}$ & $\begin{array}{l}\text { HbAlc }<6.6 \% \\
(48.6 \mathrm{mmol} / \mathrm{mol}) \\
\%\left(\mathrm{n} / \text { population } \mathrm{n}^{\mathrm{a}}\right)\end{array}$ & $\begin{array}{l}\text { HbAlc }<7.0 \% \\
(53 \mathrm{mmol} / \mathrm{mol}) \\
\%\left(\mathrm{n} / \text { population } \mathrm{n}^{\mathrm{a}}\right)\end{array}$ & $\begin{array}{l}\text { HbA } \mid c \leq 7.5 \% \\
(58 \mathrm{mmol} / \mathrm{mol}) \\
\%\left(\mathrm{n} / \text { population } \mathrm{n}^{\mathrm{a}}\right)\end{array}$ \\
\hline T2D $(2,72 \mathrm{I})$ & $32(858 / 2,7 \mid 0)$ & $42(1,|32 / 2,7| 0)$ & $56(|, 5| 4 / 2,7 \mid 0)$ & $75(2,037 / 2,7 \mid 0)$ \\
\hline TID (599) & II (68/597) & $16(97 / 597)$ & $25(147 / 597)$ & $46(277 / 597)$ \\
\hline Controls $(4,255)$ & $98(4, \mid 85 / 4,25 I)$ & $99(4,206 / 4,25 I)$ & $99(4,226 / 4,25 I)$ & $100(4,237 / 4,25 \mid)$ \\
\hline
\end{tabular}

Note: aPopulation $\mathrm{n}$ : Population $(\mathrm{N})$ minus missing values.

Abbreviations: TID, type I diabetes; T2D, type 2 diabetes; HbAIc, glycated hemoglobin.

Table 3A Percentage and number of females fulfilling the stated key criteria

\begin{tabular}{|c|c|c|c|c|c|}
\hline $\begin{array}{l}\text { Population, } \\
\text { women }(\mathbf{N})\end{array}$ & $\begin{array}{l}\text { Systolic blood pressure } \\
<140 \mathrm{mmHg} \\
\%\left(\mathrm{n} / \text { population } \mathrm{n}^{\mathrm{a}}\right)\end{array}$ & $\begin{array}{l}\text { Diastolic blood } \\
\text { pressure }<90 \mathrm{mmHg} \\
\%\left(\mathrm{n} / \text { population } \mathrm{n}^{\mathrm{a}}\right)\end{array}$ & $\begin{array}{l}\text { Triglycerides < } .7 \\
\mathrm{mmol} / \mathrm{L} \\
\%\left(\mathrm{n} / \text { population } \mathrm{n}^{\mathrm{a}}\right)\end{array}$ & $\begin{array}{l}\text { LDL }<2.6 \mathrm{mmol} / \mathrm{L} \% \\
\left(\mathrm{n} / \text { population } \mathrm{n}^{\mathrm{a}}\right)\end{array}$ & $\begin{array}{l}\mathrm{HDL} \geq 1.3 \mathrm{mmol} / \mathrm{L} \\
\%\left(\mathrm{n} / \text { population } \mathrm{n}^{\mathrm{a}}\right)\end{array}$ \\
\hline T2D $(1,052)$ & $39(403 / 1,040)$ & $71(734 / 1,040)$ & $56(59 \mid / /, 047)$ & $68(7 / 3 / 1,047)$ & $57(594 / I, 047)$ \\
\hline TID (234) & $60(139 / 231)$ & $85(197 / 231)$ & $90(210 / 234)$ & $69(161 / 234)$ & $86(202 / 234)$ \\
\hline Controls $(1,873)$ & $58(1,079 / 1,859)$ & $73(1,350 / 1,859)$ & $86(1,606 / 1,868)$ & $27(498 / 1,868)$ & $85(1,578 / 1,868)$ \\
\hline
\end{tabular}

Note: aPopulation n: Population $(\mathrm{N})$ minus missing values.

Abbreviations: HDL, high density lipoprotein; LDL, low density lipoprotein; TID, type I diabetes; T2D, type 2 diabetes.

Table 3B Percentage and number of males fulfilling the stated key criteria

\begin{tabular}{|c|c|c|c|c|c|}
\hline Population, men (N) & $\begin{array}{l}\text { Systolic blood } \\
\text { pressure } \\
<140 \mathrm{mmHg} \\
\%\left(\mathrm{n} / \text { population } \mathrm{n}^{\mathrm{a}}\right)\end{array}$ & $\begin{array}{l}\text { Diastolic blood } \\
\text { pressure } \\
<90 \mathrm{mmHg} \\
\%\left(\mathrm{n} / \text { population } \mathrm{n}^{\mathrm{a}}\right)\end{array}$ & $\begin{array}{l}\text { Triglycerides } \\
<1.7 \mathrm{mmol} / \mathrm{L} \\
\%\left(\mathrm{n} / \text { population } \mathrm{n}^{\mathrm{a}}\right)\end{array}$ & $\begin{array}{l}\text { LDL }<2.6 \mathrm{mmol} / \mathrm{L} \\
\%\left(\mathrm{n} / \text { population } \mathrm{n}^{\mathrm{a}}\right)\end{array}$ & $\begin{array}{l}\mathrm{HDL} \geq 1.0 \mathrm{mmol} / \mathrm{L} \\
\%\left(\mathrm{n} / \text { population } \mathrm{n}^{\mathrm{a}}\right)\end{array}$ \\
\hline T2D $(1,669)$ & $29(473 / 1,652)$ & $62(1,027 / 1,650)$ & $60(994 / 1,665)$ & $69(1,152 / 1,665)$ & $72(1,205 / 1,665)$ \\
\hline TID (365) & $46(164 / 358)$ & $75(268 / 358)$ & $85(309 / 365)$ & $67(244 / 365)$ & $91(331 / 365)$ \\
\hline Controls $(2,382)$ & $36(860 / 2,365)$ & $54(1,267 / 2,365)$ & $76(1,809 / 2,374)$ & $24(58 \mathrm{I} / 2,374)$ & $90(2,135 / 2,374)$ \\
\hline
\end{tabular}

Note: apopulation n: Population $(\mathrm{N})$ minus missing values.

Abbreviations: HDL, high density lipoprotein; LDL, low density lipoprotein; TID, type I diabetes; T2D, type 2 diabetes. 


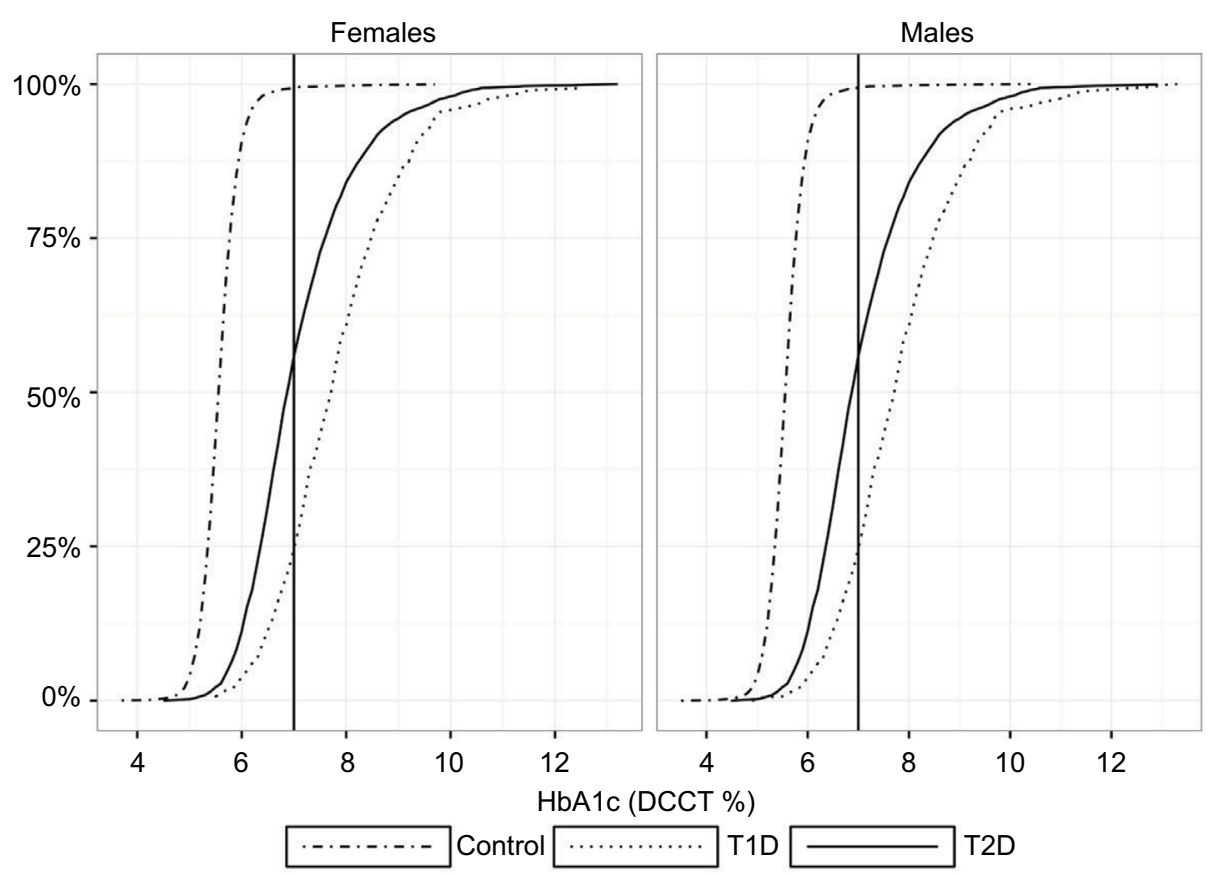

Figure $3 \mathrm{HbAlc:}$ Cumulative percentage of individuals and $\mathrm{HbAlc}(\%)$, females and males, respectively, in T2D patients (solid curve), TID patients (dotted curve), and control individuals (dot-dash curve). Vertical solid line: $\mathrm{HbAlc}=7 \%$.

Abbreviations: DCCT, Diabetes Control and Complication Trial; TID: type I diabetes; T2D: type 2 diabetes; HbAIc, glycated hemoglobin.

A

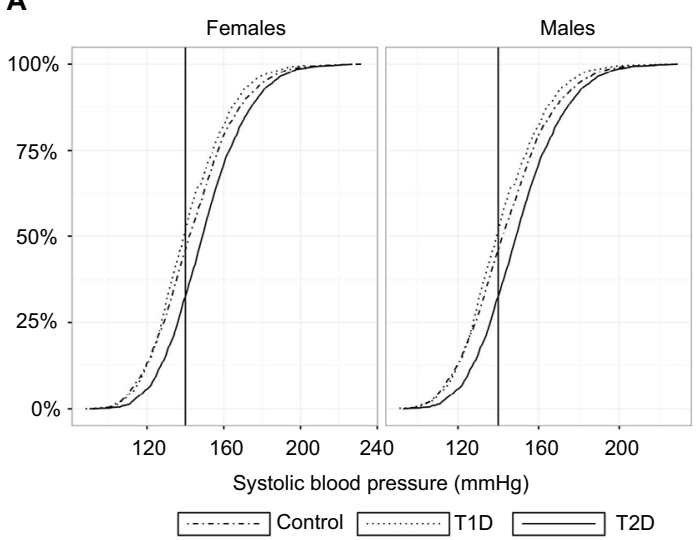

B

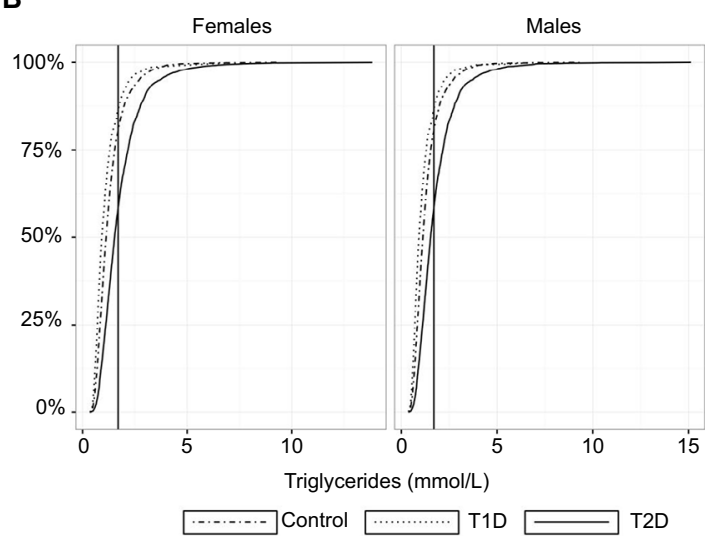

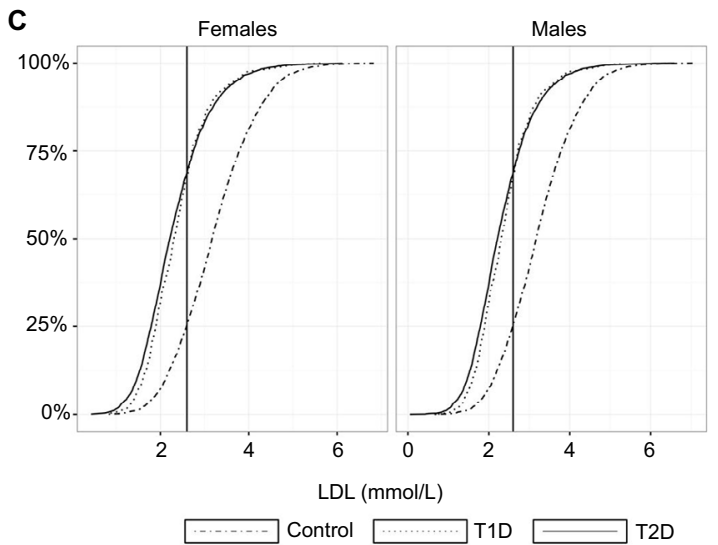

Figure 4 (A) Cumulative percentage of individuals and systolic blood pressure ( $\mathrm{mmHg}$ ), females and males, respectively, in T2D patients (solid curve), TID patients (dotted curve) and control individuals (dot-dash curve). Vertical solid line: systolic blood pressure $=140 \mathrm{mmHg}$. (B) Cumulative percentage of individuals and triglycerides (mmol/L), females and males, respectively, in T2D patients (solid curve), TID patients (dotted curve), and control individuals (dot-dash curve). Vertical solid line: triglycerides =I.7 $\mathrm{mmol} / \mathrm{L}$. (C) Cumulative percentage of individuals and LDL ( $\mathrm{mmol} / \mathrm{L}$ ), females and males, respectively, in T2D patients (solid curve), TID patients (dotted curve), and control individuals (dot-dash curve). Vertical solid line: $\mathrm{LDL}=2.6 \mathrm{mmol} / \mathrm{L}$.

Abbreviations: LDL, low density lipoprotein; TID, type I diabetes; T2D, type 2 diabetes. 
Table 4 Percentage and number of subjects fulfilling the stated criteria

\begin{tabular}{|c|c|c|c|c|}
\hline Population (n) & $\begin{array}{l}\text { Blood pressure } \\
<140 / 90 \mathrm{mmHg} \\
\%\left(\mathrm{n} / \text { population } \mathrm{n}^{\mathrm{a}}\right)\end{array}$ & $\begin{array}{l}\text { Lipids }(L D L, H D L, \\
\left.\text { triglycerides }{ }^{\mathrm{b}}\right) \\
\%\left(\mathbf{n} / \text { population } \mathbf{n}^{\mathrm{a}}\right)\end{array}$ & $\begin{array}{l}\text { Treated with ACE-inhibitors or AT2- } \\
\text { antagonists } \\
\%\left(n / \text { population } n^{a} \text { being treated with }\right. \\
\left.\text { antihypertensive agents }{ }^{a}\right)\end{array}$ & $\begin{array}{l}\text { Aged } \geq 40 \text { years and } \\
\text { treated with statins } \\
\%(n)\end{array}$ \\
\hline T2D (2,72I) & $28(745 / 2,690)$ & $34(9|0 / 2,7| 2)$ & $81(1,738 / 2,136)$ & $74(1,983)$ \\
\hline TID (599) & $48(284 / 589)$ & $55(327 / 597)$ & $89(292 / 329)$ & $63(295)$ \\
\hline Controls $(4,255)$ & $40(1,699 / 4,222)$ & $20(844 / 4,240)$ & $50(589 / 1,172)$ & $17(690)$ \\
\hline
\end{tabular}

Notes: aPopulation n: Population (N) minus missing values, 'LDL $<2.6 \mathrm{mmol} / \mathrm{L}$, triglycerides $<1.7 \mathrm{mmol} / \mathrm{L}, \mathrm{HDL} \geq \mathrm{I} \mathrm{mmol} / \mathrm{L}$ in men/ HDL $\geq 1.3 \mathrm{mmol} / \mathrm{L}$ in women.

Abbreviations: ACE, angiotensin-converting-enzyme inhibitors; AT2, angiotensin 2 receptor antagonist; HDL, high density lipoprotein; LDL, low density lipoprotein; TID, type I diabetes; T2D, type 2 diabetes.

T2D patients aged $\geq 40$ years having a serum total cholesterol $>4.5 \mathrm{mmol} / \mathrm{L}$ and not being treated with statins was $44 \%$ (Table 5). Thirty-four percent of the T2D and 55\% of the T1D patients met treatment targets for serum lipids (Table 4).

\section{Discussion}

Behind the idea of establishing the Vejle Diabetes Biobank was an intention to increase the etiological knowledge about $\mathrm{T} 2 \mathrm{D}$ and its comorbidities and to enhance the quality of diabetes care on the population level as well as for the individual patient. Along with the expanding genetic knowledge and the economic restriction in most healthcare systems, there has been a growing demand for individually precision tailored and targeted intervention. Biorepositories are in this regard most valuable resources as they allow for investigation of etiologies and intermediate, predictive, and prognostic biomarkers of disease of interest as well as of comorbidities; hence, new analytical tests with potential predictive value for diabetes or its related complications can be tested before being used prospectively. ${ }^{30}$

The strength of the Vejle Diabetes Biobank is its well-characterized individuals, completeness, and extent of laboratory, genetic, and anthropometric variables. This provides valuable data on modifiable lifestyle cardiovascular risk factors as body weight, BMI, blood pressure, smoking status,

Table 5 Highlights of findings for T2D and TID patients

Facts for T2D:
$56 \%$ reach $\mathrm{HbAlc}<7.0 \%$ ( $53 \mathrm{mmol} / \mathrm{mol})$
$28 \%$ reach blood pressure $<140 / 90 \mathrm{mmHg}$
$34 \%$ meet treatment target for lipids
$44 \%$ of patients with total cholesterol $>4.5 \mathrm{mmol} / \mathrm{L}$ are not treated with
statins
Facts for TID:
$25 \%$ reach HbAlc $<7.0 \%(53 \mathrm{mmol} / \mathrm{mol})$
$48 \%$ reach blood pressure $<140 / 90 \mathrm{mmHg}$
$55 \%$ meet treatment target for lipids
$44 \%$ of patients with total cholesterol $>4.5 \mathrm{mmol} / \mathrm{L}$ are not treated with
statins

Abbreviations: TID, type I diabetes; T2D, type 2 diabetes; HbAIc, glycated hemoglobin. and physical activity. The possibility of linkage between the cohort and various Danish national population registries (eg, the Danish National Patient Registry, the Danish Civil Registration System and the Danish National Prescription Registry) gives access to consecutive information on the diabetes prognosis. The Vejle Diabetes Biobank represents one of the largest diabetes case-control cohorts in Denmark sampled from the same geographic area. Another biobank, the nationwide Danish Diabetes DD2 cohort, has since spring 2011 systematically collected and stored blood, urine, and obtained questionnaires from newly diagnosed T2D patients. ${ }^{31-33}$ This gives unique follow-up possibilities from time of diagnosis, but only $~ 5 \%$ of incident T2D patients per year are enrolled in the DD2 cohort ${ }^{30}$ making the risk of selection bias substantially high. Further, the DD2 has no control cohort. In the Vejle Diabetes Biobank, both the diabetes and the control population show a response rate of $39 \%-40 \%$. This is a level corresponding to similar investigations based on voluntary participation. ${ }^{34}$

The limitation of the Vejle Diabetes Biobank is the lack of repeated sampling and repeated questionnaires over time, thus limiting the laboratory data and anthropometrics to the time of entry into the cohort. This can however partly be compensated by the ability to search clinical and laboratory data covering all patients in the region, and stored in national accessible registries. Further, the study is limited by the fact that the study participants have not been followed from their birth or the time of diagnosis and delayed entry will bias all attempts on absolute mortality estimation. ${ }^{35}$

As previously demonstrated, ${ }^{36}$ only $8 \%$ in 1993 and 22\% in 2001 of patients with diabetes in the Vejle County had $\mathrm{HbA1c}$ below the 99.9 percentile limit of $6.6 \%(48.6 \mathrm{mmol} /$ mol). In 2007-2010, 37\% (42\% of patients with T2D and $16 \%$ patients with T1D) were below the $6.6 \%$ limit, which is a significant increase in percentage of diabetes patients achieving glycemic regulation (HbAlc) below $6.6 \%$ of 29 and 15 percentage points, respectively. The former statistics was performed on the basis of all $\mathrm{HbA} 1 \mathrm{c}$ measures available 
in the laboratory database in the Vejle County from both hospitals and primary care centers, counting both T2D and T1D patients. In the present study, the statistics analyses were done only among the Vejle Diabetes Biobank participants (40\% responders). This fact might contribute to a better result due to the selection bias as it is well known that participants often are of better health and belong to a higher socioeconomic group than the nonparticipants. ${ }^{22}$ Consistent with this, the authors previously showed that participants in the Vejle Diabetes Biobank, both diabetic and control individuals, had a significantly lower number of registered diagnoses, ie, lower Charlson Comorbidity Index Score, ${ }^{37}$ than their nonparticipant counterparts and demonstrated all over healthier biomarkers. ${ }^{38}$

Having improved diabetes care over the years by better glycemic regulation and increased focus on the importance of controlling the patient's cardiovascular risk factors ${ }^{39,40}$ and modifying the lifestyle, there still seems to be room for improvement as only less than six out of ten T2D patients $(56 \%)$ and only one out of four T1D patients $(25 \%)$ in this cohort (2007-2010) fulfilled the international consensus treatment goals of HbA1c $<7 \%$. Nationally, $70 \%$ of T2D and $44 \%$ of T1D patients achieved a glycemic level at or under $7.5 \%$ in $2014-2015 ;{ }^{41}$ in this cohort, the corresponding numbers were $75 \%$ and $46 \%$, respectively (Table 2 ), thus slightly better than the reported present national average. ${ }^{41}$

In Germany, a significant improvement of 33 percentage points in glycemic regulation over a 10 -year time period was observed among a cohort of T2D patients, as $32 \%$ of the patients in $1997-1999(\mathrm{n}=333)$ versus $65 \%$ in $2008-2011$ $(\mathrm{n}=526)$ had an $\mathrm{HbA1c}<7 \%,{ }^{42}$ thus a superior result compared to what the authors found.

Only $28 \%$ of the T2D patients achieved treatment target for blood pressure (140/90 $\mathrm{mmHg}$ ) compared with $48 \%$ in T1D patients. In this cohort, $81 \%$ and $89 \%$ of T2D and T1D patients, respectively, were treated with ACE-inhibitors or AT2 antagonists, thus fulfilling the guidelines on anti-hypertensive treatment in which the first choice is either an ACE-inhibitor or AT2 antagonist. Of the T2D patients aged 40 years or more, $74 \%$ were treated with lipid-lowering agents; still, $44 \%$ of diabetes patients having total cholesterol values $>4.5 \mathrm{mmol} / \mathrm{L}$ were not treated with statins and only $34 \%$ of the T2D patients met the treatment target for lipids. Today, increased awareness of the importance of controlling the patients' cardiovascular risk factors may lead to more extended use of lipid-lowering agents and more intensive use of antihypertensive treatment, thereby reducing diabetes related cardiovascular morbidity and mortality. ${ }^{43,44}$ Even so, the Guidance study ${ }^{45}$ found scope for further improvement in diabetes care $(\mathrm{HbA1c}$, blood pressure, and LDL) in eight European countries.

At present, the Vejle Diabetes Biobank has led to various publications in the field of diabetes, metabolism, and genetics $^{16,38,46-57}$ and is continuously an open resource for international and national researchers. Thus, all research groups are invited to contact the authors and present their scientific hypotheses on a collaborative basis to have access to biological materials and available clinical data.

\section{Data access}

Data on biomarkers in anonymized form can be accessed at http://da.dk/catalogue/19269?lang=en

\section{Acknowledgments}

The project was funded by the Danish Council for Independent Research/Medical Sciences, the Research Council of Vejle Hospital, the Department of Internal Medicine, Vejle Hospital, Vejle County, the Danish Research Fund, the Lions Club International Denmark, and anonymous donations.

The authors would like to thank the laboratory technologists Britta Kristensen, Lene Juul Hansen, Annette Kaaris, Jan Johannsen, Merete Willumsen, Birgitte Henriksen, Camilla Davidsen, and Sara Egsgaard for their continued engagement and dedicated work.

\section{Disclosure}

The authors report no conflicts of interest in this work.

\section{References}

1. Ricchiuti V, Gunter EW, Vaught J. Biorepositories: Worth Their Weight in Gold. American Association for Clinical Chemistry; Washington, DC:2011. [CD-ROM] Product ID: 6634.

2. Castillo-Pelayo T, Babinszky S, LeBlanc J, Watson PH. The importance of biobanking in cancer research. Biopreserv Biobank. 2015;13(3): 172-177.

3. Pedersen CB. The Danish Civil Registration System. Scand J Public Health. 2011;39(7 Suppl):22-25.

4. Pedersen CB, Gotzsche H, Moller JO, Mortensen PB. The Danish Civil Registration System. A cohort of eight million persons. Dan Med Bull. 2006;53(4):441-449.

5. Kristensen JK, Sandbaek A, Lassen JF, Bro F, Lauritzen T. Use and validation of public data files for identification of the diabetic population in a Danish county. Dan Med Bull. 2001;48(1):33-37.

6. Christiansen JU, Maruard CD, Nielsen HC. LABKA. A real-time computer system for the clinical laboratory. Scand J Clin Lab Invest Suppl. 1989;194:57-61.

7. Kildemoes HW, Sorensen HT, Hallas J. The Danish National Prescription Registry. Scand J Public Health. 2011;39(7 Suppl):38-41.

8. WHO Collaborating Centre for Drug Statistics Methodology. Norwegian Institute of Public Health. Available from: http://www.whocc.no/ atc_ddd_index/.Accessed August 7, 2016.

9. Schmidt M, Schmidt SA, Sandegaard JL, Ehrenstein V, Pedersen L, Sorensen HT. The Danish National Patient Registry: a review of content, data quality, and research potential. Clin Epidemiol. 2015;7:449-490. 
10. Lynge E, Sandegaard JL, Rebolj M. The Danish National Patient Register. Scand J Public Health. 2011;39(7 Suppl):30-33.

11. World Health Organization. International Statistical Classification of Diseases and Related Health Problems. Geneva: World Health Organization .10th Revision, ICD-10: Version; 2016.

12. Keys A, Fidanza F, Karvonen MJ, Kimura N, Taylor HL. Indices of relative weight and obesity. J Chronic Dis. 1972;25(6):329-343.

13. World Health Organization. Waist Circumference and Waist-Hip Ratio: Report of a WHO Expert Consultation. Geneva: WHO Library Cataloguing-in-Publication Data. 8-11; 2008.

14. Nielsen AA. Optimization of a regional algorithm for the identification of patients with diabetes for establishing a "Biobank of patients with diabetes" and comparison with the Danish national algorithm. Estimating the number of undiagnosed patients with diabetes after introduction of $\mathrm{HbA} 1 \mathrm{c}$ for diagnosis - translation from Danish. PhD Thesis at the Faculty of Health Sciences at the University of Southern Denmark. January 2014:1-206.

15. Levey AS, Stevens LA, Schmid CH, et al. A new equation to estimate glomerular filtration rate. Ann Intern Med. 2009;150(9):604-612.

16. Nielsen AA, Petersen PH, Green A, Christensen C, Christensen H, Brandslund I. Changing from glucose to $\mathrm{HbA} 1 \mathrm{c}$ for diabetes diagnosis: predictive values of one test and importance of analytical bias and imprecision. Clin Chem Lab Med. 2014;52(7):1069-1077.

17. Danish Institute for External Quality Assurance for Laboratories in Health Care, DEKS. Danish.

18. Fraser CG. Biological Variation: From Principles to Practice. Washington, DC: AACC Press; 2001.

19. Westgard JO, Carey RN, Wold S. Criteria for judging precision and accuracy in method development and evaluation. Clin Chem 1974;20(7):825-833.

20. International EQAS - Ensuring excellent results - Labquality. Available from: http://www.labquality.fi/eqa-eqas/. Accessed December 23, 2015.

21. Quality Assurance of laboratory activities in general practices (Kvalitetssikring af laboratoriemedicinske aktiviteter i almen praksis - translated from Danish). 2010. Available from: http://www.laeger.dk/ nyhed/download/docs/F26051/kvalitetssikring\%20og\%20kvalitetskrav\%20hovedrapport.pdf. Accessed December 23, 2015.

22. Tjonneland A, Olsen A, Boll K, Stripp C, Christensen J, Engholm G, Overvad K. Study design, exposure variables, and socioeconomic determinants of participation in Diet, Cancer and Health: a population-based prospective cohort study of 57,053 men and women in Denmark. Scand J Public Health. 2007;35(4):432-441.

23. American Diabetes Association. Glycemic targets. Diabetes Care 2015;38(Suppl 1):S33-S40.

24. Inzucchi SE, Bergenstal RM, Buse JB, et al. Management of hyperglycaemia in type 2 diabetes: a patient-centered approach. Position statement of the American Diabetes Association (ADA) and the European Association for the Study of Diabetes (EASD). Diabetologia. 2012;55(6):1577-1596.

25. Inzucchi SE, Bergenstal RM, Buse JB, et al. Management of hyperglycemia in type 2 diabetes: a patient-centered approach: position statement of the American Diabetes Association (ADA) and the European Association for the Study of Diabetes (EASD). Diabetes Care. 2012;35(6):1364-1379.

26. Inzucchi SE, Bergenstal RM, Buse JB, et al. Management of hyperglycemia in type 2 diabetes, 2015: a patient-centered approach: update to a position statement of the American Diabetes Association and the European Association for the Study of Diabetes. Diabetes Care. 2015;38(1):140-149.

27. Inzucchi SE, Bergenstal RM, Buse JB, et al. Management of hyperglycaemia in type 2 diabetes, 2015: a patient-centred approach. Update to a position statement of the American Diabetes Association and the European Association for the Study of Diabetes. Diabetologia. 2015;58(3):429-442.

28. Jorgensen LG, Brandslund I, Stahl M, Hyltoft Petersen P, Iversen S, Klitgaard N, de Fine Olivarius N. Upper reference limit, analytical quality specifications and clinical use of haemoglobin A1C. Scand $J$ Clin Lab Invest. 2002;62(8):609-622.
29. American Diabetes Association. Cardiovascular disease and risk management. Diabetes Care. 2015;38(Suppl 1):S49-S57.

30. Christensen H, Nielsen JS, Sorensen KM, Melbye M, Brandslund I. New national Biobank of The Danish Center for Strategic Research on Type 2 Diabetes (DD2). Clinical Epidemiol. 2012;4:37-42.

31. Nielsen JS, Thomsen RW, Steffensen C, Christiansen JS. The Danish Centre for Strategic Research in Type 2 Diabetes (DD2) study: implementation of a nationwide patient enrollment system. Clinical Epidemiol. 2012;4(Suppl 1):27-36.

32. Thomsen RW, Friborg S, Nielsen JS, Schroll H, Johnsen SP. The Danish Centre for Strategic Research in Type 2 Diabetes (DD2): organization of diabetes care in Denmark and supplementary data sources for data collection among DD2 study participants. Clin Epidemiol. 2012;4(Suppl 1):15-19.

33. Thomsen RW, Nielsen JS, Ulrichsen SP, Pedersen L, Hansen AM, Nilsson T. The Danish Centre for Strategic Research in Type 2 Diabetes (DD2) study: collection of baseline data from the first 580 patients. Clin Epidemiol. 2012;4:43-48.

34. Tolonen H, Koponen P, Aromaa A, et al, editors. Review of Health Examination Surveys in Europe. Helsinki, Finland: National Public Health Institute; 2008.

35. Keiding N. Independent Delayed Entry. Columbus, Ohio, USA: Kluwer Academic Publisher; 1992.

36. Jorgensen LG, Petersen PH, Christensen C, Eriksen EW, Brandslund I. Improvement in glycemic control over 11 years in patients monitored for diabetes in one county. Clin Chem Lab Med. 2006;44(1): 92-98.

37. Charlson ME, Pompei P, Ales KL, MacKenzie CR. A new method of classifying prognostic comorbidity in longitudinal studies: development and validation. $J$ Chronic Dis. 1987;40(5):373-383.

38. Nielsen AA, Christensen H, Lund ED, Christensen C, Brandslund I, Green A. Diabetes mortality differs between registers due to various disease definitions. Dan Med J. 2014;61(5):A4840.

39. Ali MK, Bullard KM, Saaddine JB, Cowie CC, Imperatore G, Gregg EW. Achievement of goals in U.S. diabetes care, 1999-2010. N Engl J Med. 2013;368(17):1613-1624

40. Saaddine JB, Cadwell B, Gregg EW, Engelgau MM, Vinicor F, Imperatore G, Narayan KM. Improvements in diabetes processes of care and intermediate outcomes: United States, 1988-2002. Ann Intern Med. 2006;144(7):465-474.

41. Danish Diabetes Database - Annual report 2014/2015. Available from: https://www.sundhed.dk/content/cms/87/4687_ kom_\%C3\%A5rsrapport_diabetes_2014_15_27082015_endelig.pdf. Accessed March 21, 2016.

42. Du Y, Heidemann C, Schaffrath Rosario A, et al. Changes in diabetes care indicators: findings from German National Health Interview and Examination Surveys 1997-1999 and 2008-2011. BMJ Open Diabetes Res Care. 2015;3(1):e000135.

43. Gaede P, Lund-Andersen H, Parving HH, Pedersen O. Effect of a multifactorial intervention on mortality in type 2 diabetes. $N$ Engl $J$ Med. 2008;358(6):580-591.

44. Gaede P, Vedel P, Larsen N, Jensen GV, Parving HH, Pedersen O. Multifactorial intervention and cardiovascular disease in patients with type 2 diabetes. $N$ Engl J Med. 2003;348(5):383-393.

45. Stone MA, Charpentier G, Doggen K, et al. Quality of care of people with type 2 diabetes in eight European countries: findings from the Guideline Adherence to Enhance Care (GUIDANCE) study. Diabetes Care. 2013;36(9):2628-2638.

46. Ahluwalia TS, Allin KH, Sandholt CH, et al. Discovery of coding genetic variants influencing diabetes-related serum biomarkers and their impact on risk of type 2 diabetes. J Clin Endocrinol Metab. 2015;100(4):E664-E671.

47. Fumagalli M, Moltke I, Grarup N, et al. Greenlandic Inuit show genetic signatures of diet and climate adaptation. Science. 2015;349(6254): $1343-1347$

48. Hansen TH, Vestergaard H, Jorgensen T, et al. Impact of PTBP1 rs 11085226 on glucose-stimulated insulin release in adult Danes. BMC Med Genet. 2015;16:17. 
49. Harder MN, Appel EV, Grarup N, et al. The type 2 diabetes risk allele of TMEM154-rs6813195 associates with decreased beta cell function in a study of 6,486 Danes. PloS one. 2015;10(3):e0120890.

50. Imamura $M$, Takahashi $A$, Yamauchi $T$, et al. Genome-wide association studies in the Japanese population identify seven novel loci for type 2 diabetes. Nat Commun. 2016;7:10531.

51. Mahajan A, Sim X, Ng HJ, et al. Identification and functional characterization of G6PC2 coding variants influencing glycemic traits define an effector transcript at the G6PC2-ABCB11 locus. PLoS Genet. 2015;11(1):e1004876.

52. Stoy J, Kampmann U, Mengel A, et al. Reduced CD300LG mRNA tissue expression, increased intramyocellular lipid content and impaired glucose metabolism in healthy male carriers of Arg82Cys in CD300LG: a novel genometabolic cross-link between CD300LG and common metabolic phenotypes. BMJ Open Diabetes Res Care. 2015;3(1):e000095.
53. Albrechtsen A, Grarup N, Li Y, et al. Exome sequencing-driven discovery of coding polymorphisms associated with common metabolic phenotypes. Diabetologia. 2013;56(2):298-310.

54. Flannick J, Thorleifsson G, Beer NL, et al. Loss-of-function mutations in SLC30A8 protect against type 2 diabetes. Nat Genet. 2014;46(4): 357-363.

55. Le Chatelier E, Nielsen T, Qin J, et al. Richness of human gut microbiome correlates with metabolic markers. Nature. 2013;500(7464): 541-546.

56. Snogdal LS, Grarup N, Banasik K, et al. Studies of association of AGPAT6 variants with type 2 diabetes and related metabolic phenotypes in 12,068 Danes. BMC Med Genet. 2013;14:113.

57. Steinthorsdottir V, Thorleifsson G, Sulem P, et al. Identification of low-frequency and rare sequence variants associated with elevated or reduced risk of type 2 diabetes. Nature Genet. 2014;46(3):294-298. 


\section{Supplementary material \\ Information for patients}

We kindly ask you to participate in the study: "Biobank for diabetes".

\section{"Biobank for diabetes"}

The prevalence of diabetes has increased during the last years, particularly the type 2 diabetes. Genetic inheritance and environmental factors play a role for the development of type 2 diabetes. The aim of this study is:

1. To establish a biobank with blood samples and urine samples from 6,000 patients with diabetes and 6,000 persons without diabetes (control persons). The collection of data will last for 2-3 years.

2. To identify biochemical and molecular markers in blood and urine samples.

3. To compare the results of diabetes patients and control persons.

4. Hopefully to find the differences in lifestyle, environmental and inheritable factors, which causes diabetes and reduces lifetime due to diabetes-related complications.

5. To apply the knowledge in prevention and treatment of current and future patients.

What are the procedures on the day of examination, when you choose to register in the Biobank?

- You only have to meet up once. You can choose Vejle, Kolding, Fredericia, or Horsens Hospital.

- The examination will take place between 7.15 and 09.30 a.m. It will take about half an hour. Height, weight, waist and hip measurement, body fat percentage, blood pressure and blood glucose will be recorded, and you will get a copy of the data.

- A number of samples will be taken for storage in the Biobank (all together about $125 \mathrm{~mL}$ blood).

- Before the day of examination you will receive a container for the urine sample, please bring the urine sample on the day of examination.

- Before the examination you will also receive a questionnaire about tobacco, alcohol, exercise etc. Please bring this as well on the day of examination.

- After the examination you are offered some breakfast and coffee or tea. (If you need to take any medication, it will be possible at this time).

\section{What to remember on the day of examination when registering in the Biobank:}

- Please fast overnight, i.e. no eating, drinking (coffee, tea, milk, alcohol, juice etc.) or smoking from 10 p.m. the day before the examination. You are allowed 1-2 glasses of water from 10.00 p.m. until the examination takes place.

- Please do not take medication for blood glucose regulation (insulin or tablets). This morning please try to avoid taking medication unless absolutely necessary until the examination has finished.

- Please do not run or ride a bike on the day of examination.

- Please remember to bring the urine sample mentioned above.

- Please remember to bring the questionnaire mentioned above.

- Moreover, you should live and eat as usually the last 3 days before examination.

\section{What are the disadvantages/risks from participating in the study?}

There is no physical risk or side effects from participating. The blood sampling might cause some temporary pain and bruise at the puncture site.

\section{What are the advantages from participation in the study?}

The study is expected to generate important information about the heritable differences in the Danish population causing diabetes and reducing the life span because of insufficient effect of the medical treatment and diabetes-related complications. Therefore, the study is useful in preventing new cases of diabetes and improving treatment for future diabetes patients. 
The study might be able show if you belong to a group with higher risk of diabetes-related complications and therefore might have an extended need for treatment to avoid complications and premature death.

\section{Can you be excluded from the study?}

No, only if you choose to.

The study can be stopped if the funding discontinues. In that case all biological samples and data will be destructed.

\section{Economy}

The study was funded by the Danish Council for Independent Research/Medical Sciences, the Research Council of Vejle Hospital, the Department of Internal Medicine, Vejle Hospital, Vejle County, and the Danish Research Fund. The budget is 12 million DDK.

Your participation in the study is completely voluntary. You can withdraw your consent at any time. The paper: "The rights of a trial subject in a biomedical research project" is attached. It is elaborated by the National Committee for Health Research Ethics.

If you have any questions, you are welcome to contact the doctors.

Sincerely,

Project manager

Ivan Brandslund

Laboratory director, dr. med, MD

Laboratory, Department of Clinical Biochemistry

Vejle Hospital

Tel: 79406500

\author{
Clinical responsible \\ Cramer Christensen \\ Consultant, dr. med, MD \\ Department of Internal Medicine \\ Vejle Hospital
}

Tel: 79406306

\section{Declaration of consent}

For the study:

\section{"Biobank for diabetes"}

The aim of the study is to establish a biobank with samples of blood and urine, stored frozen for subsequent research. Do you permit that your blood and urine samples are collected in the biobank and subsequently used for identifying biochemical and heritable markers? (Please mark with a cross)

Yes

No

In this study we might find out that certain persons have specific changes in the biochemical markers increasing the risk for complications to diabetes (e.g. thrombus in the heart, diabetic eye disorder, or calcification).

If assuming that we can improve the treatment of your diabetes, do you want to get information about the findings in your particular blood samples? (Please mark with a cross)

Yes

No

You can change your decision about this information anytime by contacting:

Laboratory, Department of Clinical Biochemistry

Vejle Hospital

Kabbeltoft 25

7100 Vejle

Tel: 79406506 
To be completed in the laboratory on the day of examination

"I hereby declare that I - given the information above orally and written - consent to participate in the former described study. I am informed that participation is voluntary and that I can withdraw my consent anytime."

Date: Name of the participant (please use capital letters) and CPR no:

Signature of the participant:

Name and signature of the clinician informing the participant:

Signature of the responsible doctor:

If you have questions to the above, please contact:

Project manager

Ivan Brandslund

Laboratory director, dr. med, MD

Department of Clinical Chemistry

Vejle Hospital, Tel: 79406500

Attachment 3: Questionnaire for patients

\author{
Clinical responsible \\ Cramer Christensen \\ Consultant, dr. med, MD \\ Department of Internal Medicine \\ Vejle Hospital, Tel: 79406306
}

\footnotetext{
To be filled in by the laboratory:

Date:

The patient is fasting, e.g. no intake of food nor medication for blood glucose regulation

(Please mark with a cross) Yes __ No N__ Other medication Yes___ No__

Height without shoes $(\mathrm{cm}) \_$Weight without shoes $(\mathrm{kg}) \_$Fat $\% \ldots$ (measured without stocking).

Fat mass $(\mathrm{kg}) \ldots$ Fat-free mass $(\mathrm{kg}) \_$Total amount of body fluid $(\mathrm{kg})$

Waist $(\mathrm{cm}) \ldots$ (measured directly on the skin)

Hip $(\mathrm{cm}) \ldots$ (measured outside clothes)

Blood pressure $(\mathrm{mmHg})$ (after 5 min of rest)
} 


\section{To be filled in by the laboratory:}

Name:

CPR no:

Address:

City code:

City:

Tel: Cell phone:

Sex: $\quad$ Male $\square \quad$ Female

Age:

Do you have diabetes type $1 \quad \square \quad 2 \quad \square \quad$ Age at onset of disease:

Do you get insulin treatment? Yes $\square \quad$ No

If yes, your age by the start of insulin treatment:

Name of the drug:

Do you smoke? Daily $\square \quad$ Occasionally $\quad \square \quad$ Ex-smoker $\quad \square \quad$ Never smoked

Alcohol consumption: $\quad$ None $\square$ Occasionally $\quad \square \quad 1-7$ units/week $\quad \square$

7-14 units/week $\square \quad$ 14-21 units/week $\square \quad$ More than 21 units/week

Do you exercise? Yes $\square \quad$ No

If yes, how many times a week___ Duration per exercise (minutes)

Intensity: $\quad$ Low $\quad \square \quad$ (e.g. walking, gardening, etc.)

Moderate $\square \quad$ (e.g. cycling, quick walking, etc.)

High $\quad \square \quad$ (e.g. spinning, badminton, running, etc.)

\section{Gestational diabetes (question for women)}

Number of pregnancies:

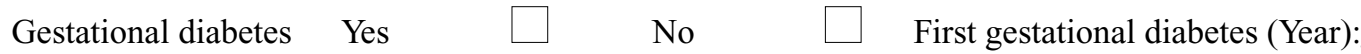

Do you have/did you have complications to diabetes in:

1) Eyes (have you had a laser treatment): Yes

No $\square \quad$ Don’t know

2) Kidney: Yes $\quad \square \quad$ No $\square \quad$ Don’t know 
3) Nerves (neuritis in the legs): $\quad$ Yes $\quad \square \quad$ No $\quad \square \quad$ Don't know $\square$

4) Feet (wounds): Yes $\quad \square \quad$ No $\quad \square \quad$ Don't know $\square$
If Yes: $\square$ Current $\quad \square \quad$ Previous $\square$

Do you have/did you have a disease in: (please mark with a cross)

1) Heart (e.g. thrombus in the heart, heart pain, etc.) $\quad$ Yes $\quad \square \quad$ No $\square$

If yes, please note the diseases:

Do you use a pacemaker: Yes

No

2) Brain (e.g. thrombus, brain hemorrhage): Yes

No

If yes, please write the diseases:

3) Poor circulation of blood in the legs: $\quad$ Yes $\quad \square$ No $\quad \square \quad$ Don't know $\quad \square$

4) Other diseases: Yes $\square$ No $\square$

If yes, please note the diseases:

Do you take any medications? $\quad$ Yes $\quad \square \quad$ No $\quad \square$

If yes, please fill in the blanket using capital letters:

\begin{tabular}{|l|l|l|l|l|l|}
\hline \multirow{2}{*}{$\begin{array}{l}\text { Name of the } \\
\text { drug }\end{array}$} & \multirow{2}{*}{$\begin{array}{l}\text { How many } \mathrm{mg} / \mathrm{mL} \\
\text { etc. per tablet }\end{array}$} & \multicolumn{2}{|l|}{ Number of tablets } \\
\cline { 3 - 6 } & & Morning & Noon & Evening & Night \\
\hline & & & & & \\
\hline & & & & & \\
\hline & & & & & \\
\hline
\end{tabular}




\section{Questions of inheritance}

Is/was your mother Danish? $\quad$ Yes $\quad \square \quad$ No $\quad \square \quad$ Don't know

If not, please note the nationality:

Is/was your father Danish? $\quad$ Yes $\quad \square \quad$ No $\quad \square \quad$ Don't know

If not, please note the nationality:

Is/was your maternal grandmother Danish? $\quad$ Yes $\quad \square \quad$ No $\quad \square \quad$ Don't know $\quad \square$

If not, please note the nationality:

Is/was your maternal grandfather Danish? Yes $\quad \square \quad$ No $\quad \square \quad$ Don't know

If not, please note the nationality:

Is/was your paternal grandmother Danish? $\quad$ Yes $\quad \square \quad$ No $\quad \square \quad$ Don't know $\quad \square$

If not, please note the nationality:

Is/was your paternal grandfather Danish? $\quad$ Yes $\quad \square \quad$ No $\quad \square \quad$ Don't know

If not, please note the nationality:

Only fill in, if the family member is/was diagnosed with diabetes

Please write the year, or mark with a cross. If you doubt whether to mark "yes" or "no" please write "don't know" or "?"

\begin{tabular}{|c|c|c|c|c|c|c|c|c|}
\hline \multirow[t]{2}{*}{ Parents } & \multirow{2}{*}{$\begin{array}{l}\text { Age when } \\
\text { diagnosed }\end{array}$} & \multicolumn{2}{|c|}{ Diet/ regimen } & \multicolumn{2}{|c|}{ Tablets } & \multicolumn{2}{|c|}{ Insulin } & \multirow{2}{*}{$\begin{array}{l}\text { Age by start of insu- } \\
\text { lin treatment }\end{array}$} \\
\hline & & Yes & No & Yes & No & Yes & no & \\
\hline \multicolumn{9}{|l|}{ Mother } \\
\hline Father & & & & & & & & \\
\hline
\end{tabular}

\begin{tabular}{|c|c|c|c|c|c|c|c|c|}
\hline \multirow[t]{2}{*}{ Siblings } & \multirow{2}{*}{$\begin{array}{l}\text { Age when } \\
\text { diagnosed }\end{array}$} & \multicolumn{2}{|c|}{ Diet/ regimen } & \multicolumn{2}{|c|}{ Tablets } & \multicolumn{2}{|c|}{ Insulin } & \multirow{2}{*}{$\begin{array}{l}\text { Age by start of } \\
\text { insulin treatmen }\end{array}$} \\
\hline & & Yes & No & Yes & No & Yes & no & \\
\hline \multicolumn{9}{|l|}{ S1: } \\
\hline S2: & & & & & & & & \\
\hline
\end{tabular}




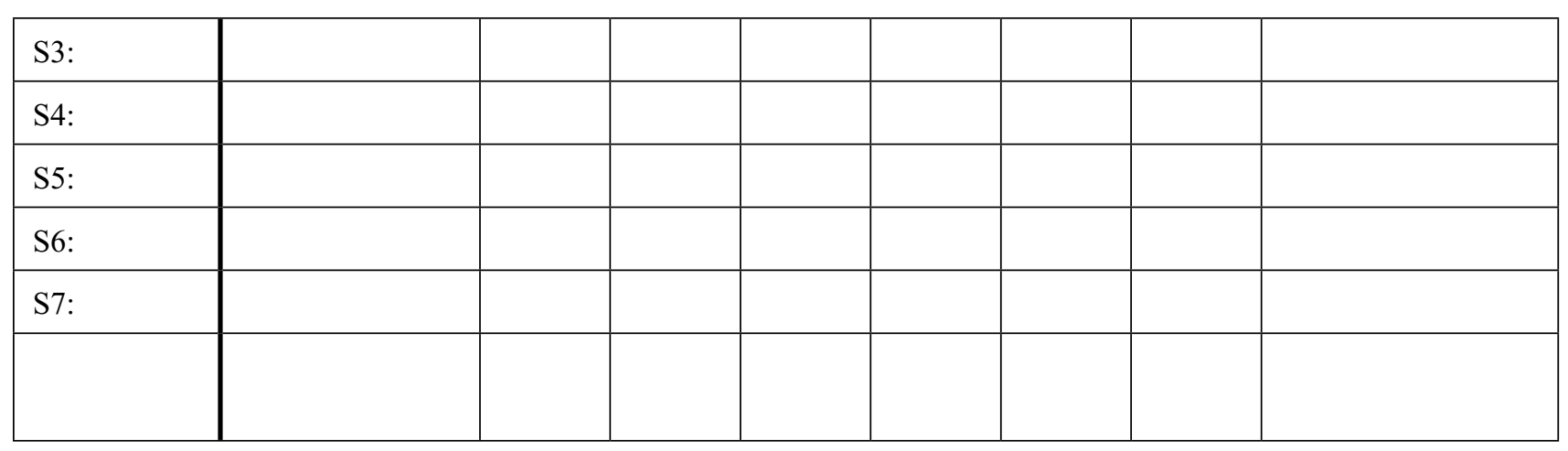

\begin{tabular}{|c|c|c|c|c|c|c|c|c|}
\hline \multirow[t]{2}{*}{ Children } & \multirow{2}{*}{$\begin{array}{l}\text { Age when } \\
\text { diagnosed }\end{array}$} & \multicolumn{2}{|c|}{ Diet/regimen } & \multicolumn{2}{|c|}{ Tablets } & \multicolumn{2}{|c|}{ Insulin } & \multirow{2}{*}{$\begin{array}{l}\text { Age by start of } \\
\text { insulin treatment }\end{array}$} \\
\hline & & Yes & No & Yes & No & Yes & no & \\
\hline \multicolumn{9}{|l|}{ B1: } \\
\hline \multicolumn{9}{|l|}{ B2: } \\
\hline \multicolumn{9}{|l|}{ B3: } \\
\hline \multicolumn{9}{|l|}{ B4: } \\
\hline \multicolumn{9}{|l|}{ B5: } \\
\hline \multicolumn{9}{|l|}{ B6: } \\
\hline B7: & & & & & & & & \\
\hline
\end{tabular}

Other family member diagnosed with diabetes (e.g. uncle, aunt, grandparents, etc.)

\begin{tabular}{|l|l|l|l|l|l|l|l|l|}
\hline \multirow{2}{*}{$\begin{array}{l}\text { Family } \\
\text { member }\end{array}$} & \multirow{2}{*}{$\begin{array}{l}\text { Age when } \\
\text { diagnosed }\end{array}$} & \multicolumn{2}{|l|}{ Diet/regimen } & \multicolumn{2}{l|}{ Tablets } & \multicolumn{2}{l|}{ Insulin } & \multicolumn{2}{l|}{$\begin{array}{l}\text { Age by start of } \\
\text { insulin treatment }\end{array}$} \\
\cline { 3 - 10 } & & Yes & No & Yes & No & Yes & no & \\
\hline & & & & & & & & \\
\hline & & & & & & & & \\
\hline & & & & & & & & \\
\hline & & & & & & & & \\
\hline & & & & & & & & \\
\hline
\end{tabular}

Clinical Epidemiology

\section{Publish your work in this journal}

Clinical Epidemiology is an international, peer-reviewed, open access, online journal focusing on disease and drug epidemiology, identification of risk factors and screening procedures to develop optimal preventative initiatives and programs. Specific topics include: diagnosis, prognosis, treatment, screening, prevention, risk factor modification,

Submit your manuscript here: https://www.dovepress.com/clinical-epidemiology-journal systematic reviews, risk and safety of medical interventions, epidemiology and biostatistical methods, and evaluation of guidelines, translational medicine, health policies and economic evaluations. The manuscript management system is completely online and includes a very quick and fair peer-review system, which is all easy to use. 